\title{
The Current HIV/AIDS Prevention Strategies-Widely Outsmarted by Omitting Realities: A Socio-Critical Analysis in the Context of Powerless Law, Ethics and Asymmetric Interpretation of Human Rights
}

\author{
Reinhard H. Dennin 1,2*, Arndt Sinn ${ }^{3}$ \\ ${ }^{1}$ Institute of Medical Microbiology and Hygiene, University of Luebeck, Campus Luebeck, Luebeck, Germany \\ ${ }^{2}$ AIDS Medical Board, Medical Association, Rostock, Germany \\ ${ }^{3}$ Centre for European and International Criminal Law Studies (ZEIS), University of Osnabrueck, Osnabrueck, \\ Germany \\ Email: ${ }^{*}$ reinhard.dennin@uk-sh.de, sinn@uos.de
}

Received 14 August 2015; accepted 27 September 2015; published 30 September 2015

Copyright (C) 2015 by authors and Scientific Research Publishing Inc.

This work is licensed under the Creative Commons Attribution International License (CC BY). http://creativecommons.org/licenses/by/4.0/

\section{(c) (i) Open Access}

\section{Abstract}

The HIV pandemic seems to be fading to some degree-but there are regional exceptions. The current liberal prevention strategy with programs aimed at risk reduction interventions in particular for sexual behavior and injecting drug use has been expanded by antiretroviral treatment approaches. It was expected to keep the prevalence of infectious individuals below a certain threshold to curb self-sustaining chains of HIV infections. The introduction of biomedical approaches by ART/HAART with regard to practicing risk reduction behavior has been received as an exemption of responsibility by certain populations who are defined as "at-risk" population. Certain parts of the hard-to-reach, high-risk population have returned to unsafe sex practices leading to careless behavior which in turn has promoted the spread of HIV. This is supported by modern trends in risk societies where with regard to HIV basic principles of ethics and tenets of the Human Rights like "don't harm other people" have lost any normative power. In addition, with the support of NGOs, legal norms such as protecting the "bodily integrity of individuals" have been ignored, allowing the "passing of HIV to partners" to become socially acceptable behavior. As a whole, in defiance of the endeavors of prevention applied so far, certain societies are exposed to an ongoing spread of HIV.

\footnotetext{
${ }^{*}$ Corresponding author.
}

How to cite this paper: Dennin, R.H. and Sinn, A. (2015) The Current HIV/AIDS Prevention Strategies-Widely Outsmarted by Omitting Realities: A Socio-Critical Analysis in the Context of Powerless Law, Ethics and Asymmetric Interpretation of Human Rights. World Journal of AIDS, 5, 275-297. http://dx.doi.org/10.4236/wja.2015.53031 


\section{Keywords}

\section{HIV Prevention, New Public Health, Risk Society, Jurisdiction, Ethics}

\section{Introduction}

Due to the ongoing spread of HIV in certain countries, despite prevention strategies and providing drugs for cART (combined Antiretroviral Therapy) and medical care in particular in high-income countries, we feel responsible for proposing the view that certain aspects of the strategies have, until now, been too short-sighted. In respect of the increasing number of problems which have developed as the sequels of a person-to-person bound viral infection that is preventable upon certain conditions, the consequences for societies as a whole have not yet been thoroughly considered.

Thirty years into the HIV pandemic, the statistics of the UNAIDS show a decline in new HIV infections globally during the last decade [1]. However, certain countries—including high income ones—show reverse trends in new HIV infections.

\section{The HIV Epidemic in Certain Global Areas}

\subsection{Characterization of the HIV Epidemic in Europe}

"The question is why we have not seen any significant progress in reducing HIV infections during the last decade. Looking at our data, we clearly see that across Europe the populations most 'at-risk' of HIV infection are not reached effectively enough, particularly men who have sex with men”, explains ECDC ${ }^{1}$ Director, Marc Sprenger [2]. "Europe has not managed to reach the 2015 Millennium Development Goal target to halt and reverse the spread of HIV/AIDS, and time is running out. While we are increasingly facing emerging health threats, this reminds us that we cannot afford dropping our guard on HIV/AIDS”, says Zsuzsanna Jakab, WHO Regional Director for Europe [2]. Sprenger adds: “... there is no cure for HIV but early diagnosis allows access to lifesaving treatment and also reduces the long term cost to the health care system". "As long as people are unaware of their HIV infection, they can unknowingly transmit the virus to others, such as partners and unborn children", stresses ECDC Director, Marc Sprenger. "And those who are unaware of their HIV status cannot benefit from earlier treatment which reduces the risk of HIV-related illness and further transmission of the virus. This is why we need to test more people for HIV across Europe" [3]. "The highest proportion was reported among MSM (40\%); heterosexual contact accounted for 34\% (including 12\% in cases from countries with generalized HIV epidemics); and injecting drug use for 6\%.” But there are variations between countries of the EU. "In 2012, 29306 diagnosed cases of HIV infection were reported in 29 EU/EEA countries (...).” There may be an underestimation due to the delay in reporting [4]. The above statements reveal the helplessness of officials in that current prevention measures have turned out to be insufficient; expressly those pertaining to HIV testing strategies. So, why were the strategies unsuccessful and what was the problem?

\subsection{The HIV Epidemic in United States-Just for Comparison}

In 2011, an estimated number of 1.2 million people are living with HIV. About $14 \%$ of them are unaware of the HIV infection. But there are differences depending on the jurisdictions [5]. The "estimated incidence of HIV (...) at about 50,000 new HIV infections per year”. “... MSM of all races and ethnicities remain the population most profoundly affected by HIV” [5].

\section{The Strategies and Concepts Mostly Applied for the Prevention of the Spread of HIV}

\subsection{The New Public Health Concept}

The concept of the New Public Health (NPH) is based on the so-called strategy of public learning which aims at 
inclusion cooperation to promote sex education, harm reduction and mass communication. A strategy of this kind must rely on a continuous and reasonable level of cognitive competence of the target people. Yet the messages, based on comprehensibility, have not been suitably tailored for the level of education nor stratified according to the various target groups, for example, those living in socially deprived areas. The intention to raise consciousness to prevent harming someone else as a consequence of HIV transmission, has failed for too many people in the target groups because of cognitive deficits. No specific programs have been launched for the comprehensive counseling of certain target group members, for example, by using individual peer-based face-to-face counselling sessions or when contacting medical services. Successful strategies that target injecting drug users, for example, through exchange programs for syringes and needles appeared later.A study performed in the Ukraine supports the "peer-led" intervention concepts to reduce new HIV infections in injecting drug users [6] ${ }^{2}$.

The NPH is focused onmono-thematic concepts rather than diversified multi-sectorial ones that meet both the various needs of the general public and those in the target groups (see section 4). In order to successfully address cognitive levels with messages about safe sex and safe use respectively, this strategy must rely on people having, at least, the cognitive potential to understand them and, based on accountability, be ready to follow the correctional messages of the prevention campaigns. Contrary to reason, it was anticipated that intellectually based messages - propagated by mass communication - that target the rational level of those people particularly at risk would be effective in achieving the necessary impact to ensure a permanent control on the evolutionary coined intimate behaviour, i.e., to limit risk behaviour. However, given the attraction of the sexual climax, which is often associated to the use of psychotropic drugs in certain "at-risk" prone settings, rationally guided behaviour is limited. The long-lasting after-effects—up to personality changes — of these drugs when used render the NPH messages useless — apart from the possible impact once infected with HIV.

Provided anonymity was guaranteed by health offices via no-name reporting if the HIV test showed positive no "contact tracing" is allowed to identify index patients. As a consequence, no counseling could and can be offered to them to interrupt chains of infections with HIV and to provide them with medical care. This also removed the opportunity to detect people unaware of their HIV infection who were not able, for various reasons, to understand the messages relayed by prevention campaigns and to implement them by adjusting their own behaviour. This was, therefore, effectively a wasted opportunity to promote the prevention programmes.

Due to the neuro-pathogenic features of HIV following infection of the CNS, neurodegenerative processes of different forms (HAND) can emerge. This becomes apparent when, for example, the patients develop such impaired neurocognitive control that may negatively influence their behavior [7]. The long-known neurocognitive impairments become more marked with progressive stages of the HIV infection [8] and are treatable [9]. It is a relevant issue, 1) because many late presenters may have engaged in risk-taking behaviour that unknowingly can spread HIV —and 2) additional health threatening sequels due to the use of psychotropic "party" drugs [10]. The adverse effects may restrict their ability to behave compliantly with the prevention messages. These HIV infected people cannot be reached to any great extent by the prevention campaigns that encourage HIV testing because too many of them may not be able to fully understand the messages.

Political decision-makers have ignored the fact that the individual's responsibility for the health of their partners must aim to protect lives; a factor that is a higher legally protected right than insisting on the individual's right to continue risky lifestyles and fostering the transmission of HIV and other STIs. This goal cannot be an arbitrary matter for negotiation among individuals regarding risky sex management, for example, serosorting, seroguessing, viral load sorting etc. The superordinate interests and the responsibility for communities have remained unconsidered.

Finally, these concepts have resulted in "HIV exceptionalism" which has subsequently promoted the stigmatisation of those infected with HIV - the "HIV stigma". This is in contrast with the measures included inpublic health principles (mostly found in "old" public health strategies) [11].

\subsection{Alternatives?}

It was an imprudent decision of those responsible for the current prevention strategy to expect their message to reach and to influence the people "at-risk", those in particular listed in Section 4. In order to reach them, quite

\footnotetext{
${ }^{2}$ Woods and J. Montaner presented the successful synergic concept of "community empowerment, harm reduction, universal success to TASP (...), needle exchange, the supervised injection site, the methadone programme for drug users ...”; Eighth International AIDS Society Conference (IAS 2015), Vancouver. Commented by R. Pebody,

http://www.aidsmap.com/Vancouvers-treatment-as-prevention-success-is-also-due-to-harm-reduction-and-addiction-treatment/page/2988230/.
} 
different concepts are necessary. Incitements to end this "HIV-exceptionalism" achieve little [12], with the exception initiated by the US Preventive Services Task Force (USPSTF) [13]. The policy of the USPSTF “... recommends HIV testing of all adults aged 15 to 65 regardless of their risk". It represents a measure that aims to overcome most, if not all, of the barriers to HIV testing-“... a long-overdue acknowledgement of the evidence as interpreted by the CDC ..." [14]. This has to be seen also in the context to reduce the number of "HIV late presenters" [15]-[17]. The initiative of the USPSTF is to be seen as targeting "at-risk" people who are unaware of their HIV-positive status because they either do not like or fear the knowledge that they are HIV-infected. In France, the initiative to test for HIV in one of the most affected target groups acknowledges the reality: "MSM (...) are recommended to screen for HIV at least once a year” [18].

Certainstudies show what Europe without a realistic concept will be forced to do manage the issues. As an example: 1) on average "a majority (60\%) of the men who had HIV did not know it..." in six selected central European capitals [19]; 2) The migrants mostly from Africa: European Union/European Economic Area (EU/ EEA) experienced during 2007-2012. "Migrants represent two-fifths of the HIV cases reported and had higher late HIV presentation.” [20]; 3) "Half of African migrants diagnosed with HIV in France acquired HIV while living there; Implications for HIV prevention strategies." [21].

The difference between migrants or refugees of varying backgrounds, respectively, with acquired HIV infection in their homelands and those with "post-migration HIV acquisition" should be of concern for the adjustment of prevention campaigns [22]. Apart from the possible impact of migrants on socio-demographic situations, the influx of ART resistant HIV and HIV non-B clades in the context of increasing the odds for the emergence of CRFs [23] needs greater attention for targeted prevention campaigns and specialized medical care services covering all their medical needs imported from their homelands. The influx of "African-born immigrants" in a certain US state points to the various challenges to come in Europe [24]. But apart from the issues with HIV-infected immigrants there is the high prevalence of HCV-infected people from sub-Saharan Africa. This situation needs the prevention campaigns for HIV to be extended for HCV [25].

At first glance, studies that try to influence "at-risk" people to change their risky behaviour by using intervention strategies on safer sex practices look promising [26] [27]. However, there is no solution as to how to achieve sustained improvements in the long term—lifelong! In particular, with the reduced threat to life expectancy following the introduction of ART, how is it possible to manage a behavioral intervention strategy that is able to reach the hundreds of thousands of individuals who are atrisk? Furthermore, what about the costs of such a strategy? With respect to the cost-effectiveness of when to screen for HIV, decision-makers should focus on targeting people in clusters in which the prevalence of HIV-positive participants can be expected to be higher than one per cent (see Section 6). This is about five times higher than that recommended for “... rapid HIV testing (...) except in settings where there is evidence that the prevalence of undiagnosed HIV infection is below 0.2\%” [28]. Thus far, discussing risk-reduction intervention strategies at a personal face-to-face level or a community level, resp. for people towards safer sex has focused on how to redirect their individual risky lifestyles. But there is a need to consider the ruling group dynamic processes regarding the participation of these people in highly organized "sex meetings" of different kinds where the individual decision-making ability is almost excluded (see Section 6).

In summary, the intended goal of current intervention strategies was to curb new HIV infections and to keep the prevalence of HIV-infected people below a certain low threshold in order to ensure that no further self-sustaining chains of HIV transmission could emerge. This, however, was, and still is an incorrect assumption. To some degree this strategy served its purpose and the majority of people responded to the health messages—but not enough people did so because the messages failed to empower an adequate proportion of those people in "atrisk" groups to reduce their risky behaviour in any way. To the contrary, these people promoted the ongoing spread of HIV. This liberal concept does not contain any restrictions regarding its misuse; it had not the required impact but has turned into a crisis. The failure of this mono-thematic NPH strategy can be taken as verification of an unsuccessful attempt. Designers of new prevention strategies have to accept realities of, example given, life settings of the "at-risk" communities. Limits for self-efficacy have to be pointed out with respect to behave responsibly within the frameworks of our liberal societies.

\section{Who Are the People Perpetuating the Spread of HIV in High-Income Countries?}

This section addresses those whose sexual orientation and promiscuous lifestyles make them most "atrisk" ir- 
respective of their social rank or education. This may pertain to anonymous loners in casual encounters, homoor heterosexual prostitution, or planned settings such as professionally organized settings such as "barebacking" of different kinds and drug users- and combinations thereof.

For the WHO/ECDC, "key populations" and "most-at-risk populations are defined (...) as men who have sex with men, transgender people, people who inject drugs, sex workers and prisoners" [29]. The categories of "at risk" and "high risk" refer, for example, to those who "... continue to engage in unprotected sexual behaviors that place others at risk for infection and place themselves at risk for contracting secondary infections...” [30]. To this needs be added sexual laxity and unrestricted promiscuity which itself poses risky behavior; as a side effect this also includes the potential for acquiring other STIs, thereby rendering these individuals susceptible to acquiring an HIV infection [31]. ECDC notes that “... multiple sexual partners, high rate of partner change, unprotected anal intercourse and oral sex (...) indicate an increase in the frequency of UAI with casual partners or with partners of HIV discordance or unknown serostatus..." [32]. A study in Switzerland confirms this trend [33]. What about the "Driving factors? (...) Molecular epidemiological data show substantial clustering of HIV infections in MSM networks, and higher rates of dual-variant and multiple-variant HIV infection in MSM than in heterosexual people in the same populations." [34]. "Speaking truth is not homophobia" [35]. Taken together all those people mentioned above have gained the status of an exceptional group.

These factual statements reveal the inadequacies of the inept measures of current prevention campaigns to reach "at-risk" people. The current risk reduction interventions have failed to have the long-term effect of curbing the spread of HIV; in other words, they have broadly failed in their intendedgoal.

\section{The WHO Global Health Sector Strategy on HIV/AIDS, 2011-2015 [36]}

The summary of the global health-sector strategy for HIV/AIDS, 2011-2015 delineates four strategic directions. It demonstrates serious engagement in that, in addition to specific aspects of the diagnosis and treatment of HIV, linkages are addressed such as sexual health as a general topic, etc. However, other STIs, such as syphilis which facilitates cross-infections and, furthermore, HCV, which may both serve as indicators for "at-risk" behavior have rarely been considered specifically [37]. In this context, the issues of HCV reinfection have to be addressed [38].

Furthermore, the problems posed by people who are unaware of their HIV infection have also not been thoroughly considered. This is despite the fact that the WHO/ECDC are aware that more than $40 \%$ of HIV-positive people who present for an HIV test are late presenters, i.e., years after they acquired an HIV infection [2]. Such complex issues have not thoroughly been considered by the WHO's "Four strategic directions". The fact remains that firmly multi-sectorial concepts that go beyond then arrow-gauged of the NPH have notyet been painstakingly considered.

An interim conclusion: To explain the broad failings of the contemporary prevention strategies solely as being a consequence of less testing is too simple a perspective. Instead of having a differentiated point of view based on real life situations of those "at-risk" populations, both representatives from the ECDC and the WHO convey the impression that they do not appear to be cognizant of, at least part of, the different causes for the failure, example given: ranging from imprudence, complacency, negligence, as well as the intentional non-compliance of those people driving forward the spread of HIV.

\section{Aside from Inadequate Testing Concepts, How Could This Happen? Clarification of Some Uncomfortable Facts}

\subsection{General Aspects}

From the outset, these prevention strategies have excluded any measures, prescriptions or tailored campaigns that may to compensate for any communication failures that can result from the failure to reach the target groups. For example, they did not address standards of education in general, the poor educational capacity of people living in poverty at the margins of society, disabled people for various reasons, socioeconomic status, or culturally specific aspects relating to immigrants [39]. Furthermore, there was no recognition of certain behavioural features of the people of the target groups, such as being prone to extreme selfishness for personal benefit, ignorance of the integrity of the health of partners, and complacency owing to the availability of cART/HAART. The 
“... lessened concern about HIV transmission due to HAART was strongly associated with sexual risk taking...” [40], there by challenging the potential for an early end-of-life [41] [42]. An about-turn of this kind, as a consequence of the availability of cART/HAART, demonstrates that the messages of the current prevention programmes are less likely to have an impact on these people. Furthermore, changed behaviour in relation to “... risky sex ...” is not due to stigmatisation or discrimination, but rather it reflects a kind of intentional change in the individual's behaviour towards risky behaviour of various kinds [42]. In particular, this pertains to the key populations defined by the WHO/ECDC.

These people could earn respect from the societies when downscaling their risky lifestyles: by self-critical showing in that they signal readiness to constructively cooperate in such a way not to perform "at-risk" sexual prone practicesand other risky practices thus not harming partners and curbing the TM/spread of HIV and other STI and to behave responsibly; i.e., avoiding any risky behavior would be the message that deserves credit. In so doing it would be acknowledged as making a responsible contribution to curb at least the spread of HIV and would help to eliminate rejection by the society if present. By not doing, but rather, insisting on lifestyles paving the way for the spread of HIV and other STI strengthen the differences- and render any efforts of prevention concepts useless in addition to increasing resistance inside the societies.

\subsection{Cluster Settings that Reflect Resistance to Any Prevention Campaigns}

“The data suggest continuing HIV transmission in many countries and that HIV remains concentrated in key populations at higher risk, such as MSM, people from countries with generalised epidemics and other migrants, and people who inject drugs and their sexual partners" [43]. According to the EU and EEA: "Similar to recent years, the highest proportion of HIV diagnoses was reported in men who have sex with men (MSM) (42\%), with heterosexual transmission the second most common transmission mode (32\%)” [43]. Both the WHO/ECDC and political decision-makers in countries relying only on NPH prevention strategies have negated the real-world settings of too many first-line actors and followers of the "at-risk" prone populations. These people are not ahomogeneous group but of various compositions, for example, they may include those who live in poverty as well as those from more affluent backgrounds.

When engaging in certain activities such as "bare backing" or similar, newcomers are subjected to peer pressure to play by the rules, they become synchronised by their common goal to satisfy the expectations of the group dynamics, i.e., to accept practices such as intentional unprotected vaginal or anal sex (UAI) among heterosexuals or gay MSM and, in particular, i.e., basing on mutual consent for a bodily injury owing to the transmission of HIV. Sessions ranging from casual ones with a few partners up to those with numerous partners in tightly organised settings are often accompanied by the use of psychotropic drugs, in particular in the course of "chem-sex" and "slamming” rituals [10]. With regard to the latter two, when taking psychotropic drugs, both may entail immediate sequels such as impaired ability for self-control, reduced ability to reason, conditioned readiness of negotiation with partners about risks, and long-term dire medical and behavioural consequences. In these kinds of cluster meetings the prevalence of HIV infected participants, both unaware and aware of their HIV infection (the latter either ART/HAART naïve or ART experienced), with sufficiently high HIV viral loads, the transmission of HIV is expected to be higher than that of the general population. Therefore, the per-event probability of HIV transmission to as yet HIV naïve individuals might result in high hit ratios. In respect of gay sex, the UAI poses an incremental effect for HIV transmission versus unprotected vaginal sex [44]. A study conducted in the UK shows that besides the sexual orientation of the participants, the impact of cluster sizeswith a low number versus a higher number of participants—on the efficiency of spreading HIV [45] $]^{3}$. Furthermore, cluster settings have to be seen as situations for accelerating the spread of TDR by cART naïve, not yet diagnosed HIV infected patients, example given, the late presenters (see section 11.7.). This has also been seen in terms of other STIs as shown for the cluster linked outbreaks of HCV [46]. Participating in such cluster meetings cannot be attributed in any way to discrimination or stigmatisation but is a voluntary decision of the participating people. Variants in settings based on serosorting and advertising, such as “only HIV-positives are

${ }^{3}$ The impact of cluster situations have been pointed out at the Conference on Retroviruses and Opportunistic Infections (CROI), Seattle/USA 2015. 1) Buskin, S.E., Herbeck, J.T., Toren, K.M.G., Perry, M.R., Bennett, A. and Golden, M. R., "Large Phylogenetically Linked HIV Cluster in King County, Washington, 2008 to 2014”, Abstract 238; 2) Oster, A.M., Wertheim, J., Campbell, E., Hernandez, A.L., Saduvala, N., Switzer, W.M., Ocfemia, M.Ch., Shankar, A. and Hall, H.I., "Growth and Geographic Spread of HIV Transmission Clusters, United States, 2007-2012”, CROI 2015, Abstract 241. 
welcome", increases the probability of acquiring an HIV dual infection, thereby facilitating the development of CRFs (see Section 11). "Negotiated safety", in case it has been done (!), does not always guarantee real awareness of his/her HIV status [47] or adequately value his/her HIV viral load (VL, see section 11.5) determined weeks or months ago-i.e., regarding HIV viral load sorting. The concomitant use of psychotropic drugs reduces the competence to realistically decide for a consensual agreement to engage in risky sexual practices. For the sake of protection by anonymity "at-risk" people are being allowed to undermine the ideals of the open society.

Furthermore, apart from the online-dating sites, "sex date", these settings are promoted by advertising via national and international networks [34]. Developments of this nature point to some kinds of parallel societies, for instance, sexual subcultures, where people follow their own norms. Such kinds of key group sessions are subjected to intrinsic group dynamic features which may become a process of spreading HIV, i.e., increasing in number of settings together with the increasing prevalence of HIV-positive people in such key groups [Fn. 3]. Such situations are potentially suited to accelerate the spread of drug-naïve HIV as well as drug resistant HIV, and because of their own dynamics of transmission are close to developing the spread of concentrated microepidemics in the key-populations. In principle, such processes could be used to reverse the trend of HIV transmission by incorporating acknowledged peers or sex workers, resp., who can change the established norms in line with the correct prevention programs, for example, by peer-driven interventions according to the "The Lucifer-Effect” [48].

Again, this trend-setting by certain sub-populations of "at-risk" people is not a consequence of discrimination or stigmatization. They represent the lifestyles of people who unswervingly undermine any sense of solidarity with communities and reflect a process of eroding solidarity. It goes without saying that solidarity, as a matter of principle, is based on duality. From the bi-directional character of solidarity it follows the principle of reciprocity. However, because no restrictions counteracting such behavior exist, both governments and NGOs tolerate one-sided interpretations of solidarity thereby indirectly fostering modes of socially destructive behavior. Public awareness about respecting "at-risk" people who in considerately continue the transmission of HIV and other STIs will be negatively influenced. Human rights advocates have to consider such problems when arguing for the protection of the human rights of those at-risk individuals who, for their own vested interests, continue to do violence against the tenets of human rights.

\subsection{Enhancement Effects Fostering the Spread of HIV}

The WHO's definition of "at-risk" populations in terms of HIV transmission (TM) meets the expression of risktaking in the context of modern trends, for example, the "western styled democratic societies" termed "risk societies" [49]. Those "at-risk" populations, —herein the context of the person-to-person HIV TM-, are, paradigmatically, subsets of the risk society. Those minorities in our societies who serisky, self-injurious behaviors and attitudes are directed against both 1) partners if causing bodily injuries to them, and 2) the tenets of human rights (HR), ethics and public health principles are causing awkward challenges for societies. This complex situation favoring the spread of HIV, now an element of the risk society, originated by means of the merging of two occurrences: a) a natural hazard, when SIVs ${ }^{4}$ crossed the species barrier to humans turning it into a modified virus, the HIV-1 and HIV-2 [50]-[52] but which may not have reached an equilibrium yet with its new human host (see section 11.), and b) its coupling with an extreme individualism established in modern "western societies" and resulting in a declining of a collective sense with detrimental social impact, " $\ldots$ and the antiauthoritarian impulse that characterized the New Left in democratic capitalist societies (...) but individualism remains central” [53]. However, individualism in the respective countries Yes—but limits have to be acknowledged in that neither violence of any kind to partners or society, nor causing harm to partner(s) occurs. This must apply to transmitting HIV to partner (s) even in consensual settings in that it infringes basic principles of Article 3 of HR. Furthermore, owing to the misuse of this kind of individualism for selfish goals directed against societal norms, far too many "at-risk" people carelessly or intentionally disengage from the guiding principles of the common good. They assume the right to continue their risky lifestyles without paying attention to the grave consequences for both partners and societies. They do not want to be helped to change their risky behavior - but they insist on receiving help when in need, for example, medical care. The lack of any restrictions outside of the legal system, coupled with rampant sexual behavior engendered by sexual laxity and unrestricted promiscuity or injecting drug use, hasled, and continues to pave the way for settings that favor the spread of HIV. c) Once established in

${ }^{4} \mathrm{SIV}$, simian immuno-deficiency virus. 
the human population, the further evolution in particular of HIV-1is continuing (example given, the CRFs, Section 11) with the help of its host, the human beings, in particular those of the "at-risk" groups and migrants and refugees from, example given, the sub-Saharan areas-“An epidemic on the move” [20].

Legal systems are almost powerless against behavior of this kind which is fostered via the specific traits of HIV. Reasonable framework conditions have to be established that limit and counteract such trends. However, nothing happened. Instead, the "at-risk" trend-settings by the people defined above have become an inherentthreat and are about to result in the risk society potentially subverting the open society (O.S) ${ }^{5}$. In respect of the ongoing spread of HIV in the western hemisphere, this trend of increasing "at-risk" behavior has to be seen as the unleashing of a new sort of violence thereby inducing tensions directed against the norms of traditionally structured societies. Advocates and proponents of these "at-risk" populations have successfully encouraged western nations to allow this risky behavior. In a certain sense, governments have surrendered to this kind of pressure thereby contravening their commitment to the societies they serve in accordance with the respective state's constitutions.

This effect has also come about because the ramifications for this approach are indirectly supported by the liberal idea of the open society. By enacting HIV prevention strategies based solely on the NPH, policymakers have not taken account of the real-world settings of "at-risk" populations; too many actors of whom intentionally have no care for the standards of responsibility for partners and society as a whole. This situation amounts to a change in paradigms and a clash of divergent movements in pluralistic democratic societies: the idea of a liberal open society relying on the responsiveness of their members versus a cult-like clash of too many of the "atrisk" people eager to continue risky sexual practices and/or drug use but being protected by the tenet of the unrestricted tolerance of the O.S. and their governments, and abusing its liberal concept. Integrating NPH into the framework of the O.S. can only be thoroughly effective if most of the members of the community manage their behaviour responsibly and follow ethical norms. This worked for some people but failed in respect of certain subsets of the extreme "at-risk" population. Indeed, unless the issue is addressed, the paradox today is that the norms allow someone to inflict a bodily injury on a partner with lethal consequences. These people play havoc with partners and societies. Misusing this gesture by not respecting the bodily integrity of other people means undermining the idea of the open society and the objectives of human rights. People continuing with both careless and intentional risk-taking lifestyles that meet their selfish desires and are without any respect for the integrity of the health of partners render both this prevention strategy and the idea of the open society powerless. Thanks to lifesaving ART, i.e., a longer life expectancy, the "at-risk" trends have gained momentum in the concrete sense of the risk society. In contrast, civilization in today's terms means everybody has to be subject to both prevailing legal and societal norms. The care systems of our societies are geared to the solidary behavior of their members. This is also an essential tenet of public health.

\section{Ethics}

A very basic norm of the traditional principles in ethics implies, do not cause harm to other people. However, for too many people, in particular those belonging to "at-risk" groups, this is no longer an option. To the contrary, actions of such kind have become something of a standard in those circles and are tolerated by the states without discussion. Ethics no longer count as behavioral norms within a regulatory context. This inherent system of "libidinal behaviour" takes precedence over ethics, vested interests matter exclusively. In fact, these "at-risk" people who cause serious damage to partners and societies are entitled to medical and social care services. Democratic systems that provide full medical/health coverage without any restrictions convey the impression that any risk to one's own health or that of partners must be covered by the society's health care systems, i.e., institutionalized insurances.

\section{Human Rights Issues}

"The international human rights system explicitly recognized HIV status as a prohibited ground of discrimination" [54]. That's correct, however: This statement, and the ongoing and generalizing accusations against the discrimination of those HIV naïve as well as HIV positive people who practice risky lifestyles promoting the

\footnotetext{
${ }^{5}$ What's next? The legalization of the "cultivation of psychotropic drugs" limited to personal use for medical application. The misuse of such regulations will most probably follow. In this context, we like to place a warning message here from Dr. Th. Frieden, (2015) CDC, USA: Heroin: The Epidemic That Knows No Boundaries. http://www.medscape.com/viewarticle/848294.
} 
spread of HIV, requires clarification. The WHO published prevalence data for HIV/AIDS: "In 2012, UNAIDS and WHO estimate that 2.2 million people were living with HIV in the WHO European Region, including 1.3 million in eastern Europe and central Asia (EECA) representing an estimated adult prevalence of $0.7 \%$ in EECA and $0.2 \%$ in western and central Europe" [55]. These data demonstrate that at least a portion of these people do not take personal responsibility nor acknowledge an absolute imperative to cooperate with the communities from which they receive help; for different reasons, they do not comply with the correctional messages of the prevention campaigns and tenets of the human rights. Advocates of PLWHA ${ }^{6}$ are forcing the general population to comply when claiming "no discrimination". Of course there should be no discrimination but advocates are confounding a justifiable refusal in the general population regarding the risky lifestyles of certain PLWHA who continue to spread HIV. Our societies have the right to have a service in return, a quid pro quo from those who are entitled to receive help.

The assessment of the Committee on Economic, Social and Cultural Rights (CESCR) on Public Health, Article 12 of the CESCR, states, "The States Parties to the present Covenant recognize the right of everyone to the enjoyment of the highest attainable standard of physical and mental health" [56]. However, this Committee also neglects the real-world settings (as described above) of too many of the "at-risk" practicing HIV-infected people who damage the physical and mental health of partners by their mutual consent, i.e., by their abuse of the liberal concepts of the prevention programs, unswerving non-compliance with HIV prevention concepts, and their defiance of the tenets of the open society and the goals of public health. Failing to position their behaviour in relation to Article 29, "Duties to the Community", of the Human Rights Declaration reflects an unbalanced presentation by the CESCR to the rights of communities. Duties are one element of human rights; they result from the mutual grant of the fundamental rights of human beings and the restriction of individual rights.

Duties are fundamental constituents of human rights. Hence, there are consequences for individuals: "Individuals, therefore, have a responsibility to behave in ways that will not harm others, for example, by not exposing their sexual or needle sharing partners to the risk of HIV infection" [57]. In order to avoid an asymmetric interpretation of the human rights of PLWHA, a balanced construction which includes their "duties to the community”, (Article 29 of the Universal Declaration of HR), is necessary.

\section{The Costs-Economical Aspects}

In addition to the ongoing spread of HIV, the number of individuals living with HIV with increased life expectancy by using ART will rise. However, many of them will suffer from different diseases [58] [59], in particular from non-communicable diseases [60] [61]. But, "Retaining HIV patients in medical care... (...) .... analyses showed that a retention in care intervention consisting of enhanced personal contact coupled with basic HIV education may be delivered at fairly low cost "[62]. Providing comprehensive care to people living with HIV is becoming tremendously monetarily challenging and damaging to national economics. Improved diagnostics and therapies apart from ART will put further economic pressure on health care systems, social benefits and social care [63]. There is growing concern about the rising costs for the increasing number of people already in medical care and using ART [64] and about the growth of drug resistant HIV. Recent data from the United Kingdom show the lifetime costs for a single HIV infected person- "30 year-old gay men, who lived to the age of 72 years”- as being $£ 360,800^{7}$, but due to generic formulations it may be down to just over $£ 100,000$ [65]. The respective data for Germany would be $£ 654,016$; this amounts essentially to the cost for cART without discounting [66]. The lifetime costs based on somewhat different defaults are of about a similar order of magnitude for, in the example given, the US [67] and Northern France [68]. A preventable person-to-person bound infection is about to become an undue health care burden on societies. Such trends have also to be seen in the context of the increasing number of CRFs (see Section 11.) [69].

\section{Jurisdiction}

\subsection{The Problems with Prosecution}

One of the most widely accepted functions of law is its role as a peacekeeper. Criminal law is the governmental response to infractions committed by anyone the law binds. Holding the perpetrator to account ends the infrac-

${ }^{6}$ PLWHA, people living with HIV/AIDS.

${ }^{7}$ In US \$ around 558,902.00 (July 27, 2015). 
tion and restores and confirms the authority of the law. And it is self-evident that a legally defined criminal offence and the culpability of the offender in violating it are necessary preconditions for this response. Many countries neither have an explicit criminal offence regarding an intentional or negligent HIV infection of another person nor do they punish the endangerment of a person through unprotected intercourse. However in some countries there are certain offences which incriminate dangerous behaviour associated with communicable diseases (cf. in Poland or in some states of the USA). The common dominator in all these criminal provisions is that injury of another person is always punishable no matter the underlying legal basis. It should be quite clear that a bodily harm can both be committed by stabbing with a knife and by transmitting a disease. The important thing is to demotionalise the discussion: talking about the punishment for transmitting HIV as only a specific and unique element of a particular criminal offence rather than a stigmatization of and discrimination against people living with HIV. The issue is one of harming another human being. If this behaviour is punishable it is a matter of the statutory definition that each society chooses for itself. The way in which these statutory definitions are applied is what is known as general criminal law. These are unemotional rules; they serve to establish equal treatment and predictability of penal sanctions and also as a restraint on state power. Criminal Law as an ultimate weapon of the government has therefore also a protective function for its citizens: every behaviour not described as incriminating is protected from sanction. Hence, the description of criminal offences as islands of restriction in a sea of freedom. The current legal discussion does not represent this factor strongly enough.

The legal situation in Germany

In Germany there is no statute that specifically incriminates the transmission of HIV; neither is the mere creation of a danger of HIV transmission specifically punishable. Instead, the criminal sanctions on HIV transmission come under the general criminal offences against life and person (§§ 223 StGB, §§ 211 StGB). According to these offences, anyone who causes injury or death to another person intentionally or negligently is punishable in line with the degree of his or her own culpability. There is no special criminal law for HIV.

The relevant provisions of $\S \S 223$, 224, as well as $\S 229$ StGB in exact wording:

$\S 223$ StGB Causing bodily harm

1) Whosoever physically assaults or damages the health of another person, shall be liable to imprisonment not exceeding five years or a fine.

2) The attempt shall be punishable.

$\S 224$ StGB causing bodily harm by dangerous means.

a) Whosoever causes bodily harm.

No. 1 - 4. (...)

No. 5. by methods that pose a danger to life,

Shall be liable to imprisonment from six months to ten years, in less serious cases to imprisonment from three months to five years.

b) The attempt shall be punishable.

$\S 229$ StGB Causing bodily harm by negligence.

Whosoever by negligence causes bodily harm to another shall be liable to imprisonment not exceeding three years or a fine.

There is no doubt that the transmission of HIV is a criminal act with regard to these provisions as an injurious behaviour. The Federal High Court of Justice (BGH) subsumes unprotected sexual contact with an HIV-positive person under the provisions named above if the infection of the sexual partner can be traced back to that specific sexual contact ${ }^{8}$. The offence is complete when the sexual partner has been infected; this is also the case with all other dangerous infections. The BGH assumes that the requirements $\S \S 223$ (1), 244 (1) No. 5 StGB (causing bodily harm by dangerous means) have been met because the infection is not curable and is regularly fatal. Although this provides legal clarification, the causal connection between sexual contact and infection is especially difficult to prove, though it is a critical element of the offence. In the case of frequent change of sexual partners, genetic tests are only partially able to shed light on the causation question. Within the aggravated offence (§ 224 (1) No. 5 StGB) there is also the additional question of whether evidence as to the accused's viral load is relevant to the question of life-threatening endangerment. However, the aggravated offences are also punishable as attempts, meaning that even if the infection cannot be causally linked to the sexual contact, an attempt can be prosecuted. Criminal liability for attempts, in turn, requires the offender to have acted intentionally. In the ruling

${ }^{8}$ Federal High Court of Justice decision dated from November $4^{\text {th }} 1988$, file No. 1 StR 262/88. 
mentioned above, the BGH decided that the accused acted with contingent intent. The court further held that the state of general knowledge about the risk of transmission during intercourse was sufficient to assume that the "knowing" element of the offence was fulfilled.

In the interest of differentiating between negligence and recklessness, the BGH chose to have a closer look at the voluntary element of intent. The BGH states that it is of course too much to say that bare knowledge of one's own HIV status plus the fact that unprotected intercourse can transmit the virus is enough to establish specific intent $^{9}$. Also the fact that the accused had a reasonable ground of assuming that the risk of infection was in fact low in this case can be an argument against his intent. Yet even in the face of comparatively low probability of infection per sexual contact, the Court held, there is the chance that every unprotected sexual contact could be the one of many to cause the transmission. Therefore every person carrying the virus actually bears the entire risk of transmission. Based on these arguments, one has to admit that the assumption that the voluntary element is a given can only be an exception, but that qualified intent may be able to be assumed.

The BGH further excludes a presumption that the injury is fatal ${ }^{10}$. Given that HIV can have a long and variable incubation period and that the offender may share the hope of many people living with HIV that a cure will be found within his lifetime, it is doubtful that the offender assumed that deadly injury could be a consequence of his behaviour. The general position in the case law is this: the perpetrator knows about the dangerousness of his behaviour. Due to this knowledge he also knows that his actions can have damaging consequences (knowledge about the concrete possibility that his sexual partner can be infected). Despite this knowledge he commits dangerous behaviour and considers the result of an offence as possible. As a consequence, even a perpetrator who does not want an infection to take place and vaguely hopes for the transmission not to happen acts intentionally. If, however, the offender genuinely believes that the offence will not be completed, he cannot be said to have acted intentionally.

Another question to be asked is whether a defence may be available to the offender because the sexual contact was consensual. A defence can only be drawn from a justifying consent e.g. in those cases in which the infected person informed his partner about the risk. The consensual sexual contact does not say anything about the question of whether the partner is informed about the risks of having intercourse with an infected person. Consent is to be measured by the offence and by the therein described risk. Thus when a person does not know about the infection, he or she is not able to consent. That is a generally accepted principle. Even the efforts to declare consensual intercourse an act of self-endangerment does not change this assumption. For an effective consent it is a mandatory requirement to be informed about the risk the person is taking. If only the one partner knows about his infection, the general awareness of the chance to become infected is not enough for a consent. A helpful analogy might be a reminder that the passenger in a car does not consent into a high risk driving attitude of the driver when getting into the car. It is not clear why we should assume something else for HIV transmission. If one of the partners does not know about the infection of his sexual partner the infected person intentionally realizes the result of an offence. The risk could be minimized very easily by informing the other person about the infection. In case the knowing partner then consensually takes the risk, this is to be respected. If he chooses to take the risk anyway, there is no way the offence can be realized. Only the infected person (risk-carrier) has knowledge about the risk, not the unaware partner. As a result, the unaware partner is unable to refuse and to protect his own health if there is no duty to disclose HIV status. It should be generally accepted that an HIV-positive person is obligated to disclose his status to potential sexual partners. It is important to recognize that infection as a result of sexual contact with the partner is an offence as discussed above. Even the prevention campaigns have to convey this message not only to the general public but also to the target audience. Once again: this is not about legal stigmatization or the establishment of a specific status. Moreover we do not ask for the impossible: it is as a general imperative rule not to injure another person, meaning to organize oneself in a way that other persons do not get harmed. It is selfish and egoistic not to grant other people their own choices by not informing them.

The offender's responsibility for his potential risk cannot be shifted to potential victims as a duty of self-protection. A role reversal of this sort is not acceptable at this point. It is uncontested that self-protection is highly recommended and it should be also communicated by prevention messages. But it is not a legal principle. It can only be evolved to a legal principle if the responsibility for oneself can be assumed. And that is only the case when the endangered person has knowledge about the risk-the person that is not aware of the danger caused

\footnotetext{
${ }^{9}$ Federal High Court of Justice decision dated from November $4^{\text {th }} 1988$, file No. 1 StR 262/88.

${ }^{10}$ Federal High Court of Justice decision dated from November $4^{\text {th }} 1988$, file No. 1 StR 262/88.
} 
by another person, cannot assume the responsibility for the situation. The right of not knowing is a way of balancing the superior knowledge of the partner with knowledge of his HIV-positive status. In the 1980s the right of not knowing was developed to escape fear and stigmatization. The current situation though does not justify this fear anymore. If we were to assert the right of not knowing it would have the following consequences: 1) In an indirect way, the consequence would be that the infected partner would not have to reveal his infection to his potential partner, since the right to not knowing is going along with the own not knowing about a potential infection of oneself. This can lead to an ignorance regarding the necessary measures for protection. As a consequence a necessary element of action will be closed off. 2) The agreement to a right of not knowing will lead to an increasing number of HIV-infected persons and is therefore tantamount to an acceptance of the spreading of HIV. It is thereby against society's interests. 3) In addition to this, there is a tactical advantage associated with the right of not knowing. The basis of the principle of shared responsibility has to be that an HIV-infected person must reveal his infection. The revealing of the infection is a part of his or her responsibility towards his/her sexual partner and towards society. To keep it a secret is to behave culpably. Even medical confidentiality can be limited or eliminated to protect a legally protected right.

The possible willingness of the sexual partner to engage in unprotected intercourse of course has to be considered within the sentencing as a possible ground for mitigation. This can for example be: a) the conscious participation in sexual intercourse which contains a high risk of infection, e.g. the conscious participation in barebacking-parties; b) participation in events involving the consumption of consciousness-altering drugs such as narcotic painkillers taken before participating in fisting; c) by convincing an HIV-positive person to have unprotected sexual intercourse with an HIV-negative person for money; d) male or female occasional prostitution, e.g. "survival sex"; e) it is also known that the willingness of unsafe sex plus high risk sex is increasing, since the prospects of successful therapies invite recklessness. This potential problem with the treatment-as-prevention approach is sadly not discussed as frequently as it should be.

To demand the decriminalization of HIV transmission is to support the decriminalization of behaviour without there really being good reason to do so. As shown, the German criminal law follows general principles of attribution of criminal behaviour without creating special offences for HIV transmission. In fact it is treating like cases alike: every deliberate and negligent dangerous behaviour is generally punishable. Questioning these principles would mean questioning constitutional safeguards (the responsibility of the state to protect its citizens, since the decriminalization would undermine the physical integrity as an object of legal protection). In addition to this it would imply an inversion of responsibilities. Not the endangered person but the HIV-positive person should be the one bear responsibility for the safety of others. Everything that differs from this principle cannot be the goal of handling HIV infection in a constitutional way. The criminal law does not discriminate against people living with HIV, but it does punish individuals for their unlawful and culpable behaviour when they deal with their illness by harming others. This approach creates the basis for differentiating forms of behaviour and serves the purpose of prosecuting all socially intolerable behaviours, which is also in the interest of the majority HIV-positive people who deal with their infection in a responsible way. Behaviour contrary to prevention e.g. is: 1) not to inform your partner about your infection; 2) not to get tested for HIV although the suspicion of being infected exists; 3) not to protect yourself while having occasional sexual contacts with others, whether at barebacking parties or otherwise.

\subsection{Will Decriminalization of HIV Transmission Help to Curb It? The Impact of Risky Behaviour on Societies}

As long as ago as 2008, UNAIDS issued the "UNAIDS Policy Brief: Criminalization of HIV Transmission” [70]. It was reasoned that "There are no data indicating that the broad application of criminal law to HIV transmission will achieve either criminal justice or prevent HIV transmission. Rather, such application risks are undermining public health and human rights." However, is there evidence based proof of the opposite conception? UNAIDS did not consider the modes of behavior within "at-risk" and at highest-risk groups, which have reoccurred since the midst 1990s; for those "at-risk" people it's not the rule to discuss the 'issues of criminal laws' ahead of negligently or intentionally practicing risky behavior favoring HIV transmission; thereby, they foil the prevention measures that meanwhile resulted in a still ongoing "resurgent ...HIV-1 epidemic..." [42]. This “... resurgent HIV-1 epidemic ..." happened in spite of the coincidental advent of improved cART. It's a widely accepted experience that people of the "at-risk" minorities continued spreading HIV as though it were a natural right guided by complacency; they don’t care about both legal norms and basic principles of Articles 3 and 29 of 
the Human Rights Act.

In this context a message from UNAIDS aimed at cultivating the citizen's duty to society would be helpful in that the individual's social consciousness would be addressed. This would need to be included in the statements of the Policy Brief and directed at the risky trends of the people:

1) Who intentionally practice sexually risky behavior as well as injecting drug users who thereby contribute to ongoing HIV transmission dynamics. Their actions are usually based on playing the odds of transmitting HIV, or are the actions of those ready to acquire an HIV infection. This message should explain the tolerance granted to those promoting a form of stealthy violence against society. It is not a matter of a few individuals; instead, these risky trends have gained the dynamic of a mass phenomenon blessed by "Queer Temporalities".

2) The controversial issues of "partner notification" have to be analyzed, balancing the pros and cons [71] [73]. In particular, the message should report studies which show that partner notification "... is a highly efficient way of detecting previously undiagnosed cases of HIV ...” [74].

\section{HIV's Traits to Outsmart Prevention Concepts}

1) The HIV- $1^{11}$ and HIV-2 (types) belong to the retrovirus family within the generic group of lentivirus. Multiple founder events for HIV-1 occurred in the western part of sub-Saharan Africawhen SIVs crossed the species barrier to humans and began in the early 1900s [75] [76]. HIV is broadly classified into four lineages, namely groups $\mathrm{M}, \mathrm{N}, \mathrm{O}$ and $\mathrm{P}$. The M-group that predominates the global pandemic is subdivided into clades (or subtypes), currently A, B... J, K. The complete HIV particle, the virion, contains two positive polarized singlestranded genomic RNA molecules. Among other products they encode for three enzymes involved in the replication of the HIV, the (error prone) reverse transcriptase, the integrase, and the proteinase. And there are further HIV genome encoded targets for new drugs such as the trans-activating proteins (tat) [77].

2) The routes of HIV infection are unprotected sexual intercourse (vaginal, anal and, to a lower extent, oral), injecting drug use, mother-to-child transmission, and occupational infections except for rare transfusion-transmitted cases depending on the region. However, if using respective precautionary measures the strictly person-to-person bound transmission of HIV is avoidable apart from certain situations (for details see Section 4).

3) Cell-free HIV mainly infects cells of the lymphocytic lineage in the blood, in particular the CD4 ${ }^{+}$T-helper (Th) cells playing a central role as key components of the immune system, cells of the macrophage lineages and, furthermore, it invades the central nervous stem (CNS) [78]. Cell-to-cell-contact transmission omitting cell free HIV is also known [79]. The infection of cells by cell-free HIV depends on the interaction of ligand molecules at the surface of the HIV with certain receptor and co-receptor molecules on the surface of these cells (entry and fusion).

4) The infection of the $\mathrm{CD} 4^{+}$Th cells by HIV impairs their function, finally ending in their destruction, i.e., their depletion in the blood. The immune system is unable to counteract the infection below a certain threshold

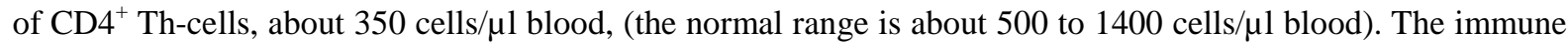
system of those individuals infected by HIV gets weakened both via the cellular immunity by means of the $\mathrm{CD} 4^{+}-\mathrm{Th} 1$ cells and the humoral immunity provided by antibodies by means of the $\mathrm{CD} 4^{+}-\mathrm{Th} 2$ cells. This applies to infectious diseases external and internal to the body (the latter ones are named opportunistic infections, for example, exacerbating tuberculosis). They are about to pose serious medical and social challenges globally.

5) A variety of antiretroviral drugs are available to specifically inhibit the HIV's genetically encoded enzymes and this interaction upon infection of cells as far as no resistance against these drugs exists. The treatment with antiretroviral drugs is named Antiretroviral Therapy (ART), combined Antiretroviral Therapy (cART) or Highly Active Antiretroviral Therapy (HAART). These drugs, specifically designed for HIV, can suppress the replication of HIV thereby allowing the immune system to recover to a certain degree. The effect of ART can experimentally be determined by measuring the viral load (VL), i.e., the HIV-RNA copy number/ml blood plasma. "The key goal of ART is to achieve and maintain durable viral suppression"12. In case of a successful suppression of the HIV VL, these patients are living longer with an improved quality of life. The term "Therapy" is misleading, because the treatment with the current antiretroviral drugs is just an intervention in the replicative

\footnotetext{
${ }^{11} \mathrm{HIV}$, Human Immuno-Deficiency Virus, type 1 and type 2, respectively.

${ }^{12}$ AIDSinfo (2014) Panel on Antiretroviral Guidelines for Adults and Adolescents. Guidelines for the Use of Antiretroviral Agents in HIV-1-Infected Adults and Adolescents. Department of Health and Human Services. Section Accessed September 4, 2015; pp. C5-C10; Available at http://aidsinfo.nih.gov/guidelines and http://aidsinfo.nih.gov/contentfiles/lvguidelines/AdultandAdolescentGL.pdf.
} 
process of the HIV; however, it is neither an eradication of the HIV nor a cure for it!

6) Which intrinsic traits of HIV cause the disarming of the host's immune system and, consequently, the medically devastating aftermath of the HIV infection in the short, as well as in the long-term horizon?

HIV establishes a persistent infection, characterized by a lifelong ongoing replication and infection of more cells as well as maintaining a stage named latency, i.e., no replication in a silenced cell, or maintaining a low-level replication rate but keeping the infected cells viable. Soon after the infection occasionally symptoms occur not specific to HIV, the Acute Retroviral Syndrome (ARS). The first-line combined "antibody and antigen" laboratory tests for HIV will show "positive" (including confirmatory tests) also for the HIV VL, i.e., these people are infectious, depending on the window period. Only after years have passed mostly asymptomatically after an infection with HIV happened, symptoms become apparent which are indicative of an HIV-infection or progressed stages of it. HIV-infected individuals who are not tested for HIV during the asymptomatic stage are unaware of their HIV infection and can unknowingly infect partners. The late-presenters mostly belong to people who ask for HIV testing as a result of symptoms related to the HIV infection appeared. However, there are a minority of HIV infected people who belong to the long-term non-progressors (LTNP) and the elite controllers [80]. The HIV infectiousness of the last mentioned cannot be excluded for certain.

7) In addition to the ongoing destruction of the $\mathrm{CD} 4^{+}$Th-cells, the HIV controls efficient strategies to escape a) the immune system after infection, b) the action of antiretroviral drugs, and c) to develop into highly diverse genetic variants resulting in a great genetic diversity which gets potentiated by the high rate of replication of the HIV [81]. This quasi-species diversity can result in the development i) of immune escape variants, ii) of drug-resistance, thus enabling it to replicate in spite of the cART/HAART provided to the patient. The spontaneous occurrence of mutations in the HIV genome responsible for drug resistance is a natural process in HIV infected patients both under the selective pressure of cART and in cART naïve ones. In both situations "drugresistant" HIV can be transmitted (transmitted drug resistance/TDR) to partners. The TDR by ART naïve HIV infected patients deserves a high priority for continuous surveillance [82] [83], both with an extended diagnosis at the molecular level of the HIV and in the context of cluster settings with regard to their size and frequency (see Section 6.2.); iii) mutations that render HIV to a more or less virulent variant, and iv) with the passage of time after a HIV transmission from person A to person B, the high rate of mutations in both A and B results in a divergence of a kind such that the individual's genetic causality of HIV-B cannot be linked to HIV-A. The onus of proof for prosecution, therefore, cannot be supplied; the HIV itself hampers criminal prosecution in most cases. To make a clear statement: The HIV infection causes a deadly outcome for most of the infected people; the application of cART/HAART does not contravene this principle.

8) A further molecular mechanism named recombination with the potential to develop greater variances in the genetic organization depends on multiple infections—at least a dual one-of one individual with two different HIV intra-clade (subtype) heterologous strains [84] or strains from different clades infecting the same host cell/s in one individual. This can happen, example given, if two individuals each infected with HIV of different clades have sex using risky practices of different kinds or if HIV infected, injecting drug users sharing blood contaminated needles. During replication of both HIV in one cell it can happen that parts of the parental gene sections recombine [85]. If able to replicate, such recombinant forms can be spread and gain epidemic scales and are then named circulating recombinant forms, CRFs [86]. One example is the HIV-1 inter-clade recombinant subtype CRF01_AE [87]. The extent to which individuals infected with different variants of CRFs will progress to AIDS remains to be followed up but there are already known aggressive HIV-1 complex recombinants, for example, the CRF19_cpx [88]. The recombinants may already contain gene sections carrying drug resistance potential from at least one sexual partner. The extent to which recombinants of this type can become prevalent, or even outsmart the currently circulating wild type HIVs, cannot, asyet, be decided.

Apart from the impact of the influx of HIV non-B subtype infection by “...migrants and refugees ..." [89], this development is with special regard to the increasing use of national and international networking contacts among "at-risk" people thereby promoting multiple HIV infections events by intra-clade resp. of different clades. The development of genetic diversities takes time depending on the chances of establishing a dual HIV infection on various conditions in one individual. Nevertheless, their stealthy emergence has gained impressive travel routes. It's a matter of facts meanwhile. The crossing of sociodemographic boundaries [90] [91], the man-made "travel routes" of different clades [92] as well as of CRFs [93] [94] are well documented and are indicative of the ongoing blending of HIV from different clades. With the support of the individual's behavior, ranging from disregarding the correct messages of prevention campaigns, negligently or intentionally omitting self-protection, 
non-complacency in terms of ART and unscrupulousness, this development will gain increasing momentum owing to the growing number of people living with HIV; at least part of them are accelerating this process by paving the way for chains of transmission and, thereby, increasing the odds for emerging variants that may possibly be more virulent [95]. Polygamous partnerships [96] and transmission cluster settings favor situations to become dually infected.

\section{Desperate Measures to Curb the Ongoing Spread of HIV}

"Eastern Europe is facing quadruple, intersecting epidemics of injecting drug use, HIV, tuberculosis (TB) and hepatitis C,..." warns the UN Special Envoy ${ }^{13}$. The "European Union must act now as Baltic states and Romania battle to control HIV", says Kazatchkine ${ }^{14}$.

\subsection{That Is Correct Not Alone for "Eastern Europe"- but What Needs to Be Done?}

The facts: the current HIV prevention programmes, aimed at "at-risk" reduction interventions only for the general population and for people belonging to the hard to reach "at-risk" groups of any kind, have not reached the expected low scale of both HIV incidence and prevalence necessary to curb the spread of HIV. There are numerous studies providing evidence-based results that since the midst 1990s the availability of cART has resulted in a reduced concern about HIV transmission, safer sex fatigue, complacency and elevated risk behavior among those spreading HIV. Based on comprehensive information from scientific and public health sources these people have had, and still have ample opportunity to manage their risky lifestyles with a view to reducing or avoiding HIV transmission but they have failed to do so. That is a consequence of liberal policies which have allowed particularly sexually active high-risk people and injecting drug users as part of the bridging people to continue their risky lifestyles thereby promoting the spread of HIV and other STIs.

In terms of the state, it is accepted that personal rights, the right of self-determination, and civil rights and liberties can be abused by too many people who are persistently pursuing their instinctive, conditioned, vested interests. They do not care about the consequences such as the breakdown of their health and the impact on the society which they look to for help when they are HIV infected. Instead, they behave in a non-compliant manner by opposing the correct messages of the prevention campaigns and, in some ways are ready to use violence towards society: “... the 'traditional' approach of broad, population-based rollout of treatment and prevention messages and technologies must be reexamined and different approaches must be considered” [97]. Governments have not reflected on their commitment to avert any damage to the communities they had been properly elected to serve. In this respect, governments are not upholding their duty to protect their uninfected citizens.

The increasing prevalence of PLWHA is about to become an unmanageable state of affairs. In terms of the unrestricted spread of HIV both the risk intervention programmes and the legal systems are powerless. The states have drawn back from the violence they tolerate.

\subsection{A Global View}

Faced with this situation, the initiative of UNAIDS seems like a desperate defensive alternative: The vision of UNAIDS is the "90-90-90" "prevention and treatment" target to bring a halt to the HIV/AIDS pandemic with a biomedical approach in particular [98]. In high-income and most of the middle-income countries this kind of the biomedical approach is already in progress. However, such biomedical interventions for HIV prevention effectively require the people receiving ART to commit to a high level of adherence to the respective regime [99]. Recent studies concerning PrEP for MSM show a continuing HIV transmission rate [100]. Since ART became widely available warnings upraised regarding drug resistant HIVs [101]. The WHO pointed to the fact that, "Significant population-level HIV drug resistance could potentially restrict future therapeutic options and in-

\footnotetext{
${ }^{13}$ In this context an example for a serious situation in Eastern Europe concerning IDU is given by Nikolai L. M. et al., (2010) High HIV Prevalence, Suboptimal HIV Testing, and Low Knowledge of HIV-Positive Serostatus among Injection Drug Users in St. Petersburg, Russia AIDS Behav, 14(4), 932-941. doi:10.1007/s10461-008-9469-y. This also includes the spread of variants of HIV caused by the bottleneck selection. Masharsky A. E. et al. (2010), A Substantial Transmission Bottleneck among Newly and RecentlyHIV-1-Infected Injection Drug Users in St. Petersburg, Russia. J. Infect. Dis., 201(11), 1697-1702.

${ }^{14}$ Kazatchkine, M., UN Secretary General's Special Envoy on HIV in Eastern Europe and central Asia, Speaking at the Opening Plenary Session of the 14th European AIDS Conference, Brussel, 2013. Comment by K. Alcom.

http://www.aidsmap.com/Eastern-Europe-facing-quadruple-epidemic-while-governments-do-nothing-warns-UN-Special-Envoy/page/27810 70/. (Accessed on 10 April 2015).
} 
crease treatment costs by requiring new and more expensive antiretroviral regimens” [102]. This has to be seen in the context of the adherence regimes [103] [104].

\subsection{The Appeal of the "Vancouver Consensus"}

It is presented at the Eighth International AIDS Society Conference 2015 sounds encouraging at first glance-by neglecting counteracting features of human behaviors of too many of the "at-risk" people [105]. The statement therein "The treatment era had begun" (already around the midst-1990s) is correct, but is it a perfect strategy? Contrary to the anticipated success, the HIV incidence rates published by the ECDC for Europe and the CDC for USA have increased since. It is too simple a conclusion to make political decision makers believe in the results of controlled cohort cART treatment studies but ignoring the real lifestyles of those defined as "at-risk" people (see chapter 4 ).

The point is that the more HIV infected people are treated with antiretroviral drugs-here the Treatment AS Prevention (TASP), the pre-exposure prophylaxis (PrEP) [106], and the Post exposure (PEP) concepts-the higher the odds of the emergence of cART resistant HIV and its transmission. In this context drug resistant HIVs, resulting from transmitted drug resistant (TDR) HIV in treatment-naïve individuals, should sound an alarming signal for policy-makers [107]-[109]. This reflects the reality that cART helps too many people to continue to engage in risk-taking lifestyles thereby promoting HIV TM and rendering void all efforts of the communities to curb the spread of HIV. These "at-risk" people thus present an extremely challenging paradox with which our liberal structured societies are faced. Several statements emphasize this situation: "Hypothetical scenario analysis shows that the epidemiological benefits of highly active antiretroviral therapy and earlier diagnosis on incidence have been entirely offset by increases in the risk behaviour rate" [42]. This statement turned out to be correct. "Indeed, current surveillance data suggest that transmissions are increasing in resource rich communities-particularly among men who have sex with men (MSM), in addition to the large epidemics ongoing within the resource-poor world. Such increases represent a public health failure” [110]. A comment on a UNAIDS action in 2004, put it starkly, "HIV outpaces global response” [111] is still valid [112]. Such developments, inherent in our social systems, demonstrate proof of failure, yet our governments seem powerless as they have no concepts or strategies to hand to deal with the situation.

Continuing "at-risk" behavior that is not compliant with the need for required adherence to methods of prevention, will increase the spread of both drug naïve and drug resistant HIV resulting in the current prevention strategies and the biomedical approaches to HIV prevention becoming useless measures. It takes time to gain momentum but it is likely to happen. Policy-makers have to explain why they continue to place the individual rights of those infected at a higher level than their duty to the community. Denying the realities of personal risk-taking behavior of the key populations by the designers of future prevention strategies and governments may effectively become toleration for the spread of HIV in general, and for drug resistant HIV in particular.

\section{Conclusions}

To some degree, the NPH strategy served its purpose and the majority of people responded to the health messages-in contrast to the "at-risk" populations in particular. By continuing with the current strategies only, our societies may be faced with a further increase in HIV prevalence-an ominous escalation threatens. The questions arise: Why are societies obliged to tolerate the increasingly ongoing trends by-mostly-subsets of members of "at-risk" populations who do not cooperate responsibly, but engage in risky practices thereby promoting the spread of HIV and undermining all prevention efforts?

The divergent threats are about to multiply by further disregarding real life settings of those "at-risk" people outlined here. As a consequence, it points to the conclusion that the current prevention strategies and concepts have to be reshaped into multi-sectorial based strategies by recognizing realities for the purpose of syndemic prevention networks [113]-[115]. They have to be developed to counteract the broad spectrum of behavior fostering noncompliance that ranges from self-complacency to intentional abuse of the liberal tenets that have underpinned the prevention strategies from the earliest days of the HIV pandemic. However, despite its deficiencies certain parts of this strategy must remain as a part of a wider package of HIV prevention strategies, i.e. continuing with improved messages for sex education, harm reduction regarding sexual practices and drug use.

Relying on biochemical approaches only corresponds to frantic efforts and may look gloomy. Therefore, based on painstaking examinations of the current concepts at a transnational level comprehensive concepts have 
to be developed which counteract the complexities of “at-risk" behaviors of those people.

\section{References}

[1] UNAIDS, Epi Slides (2014) http://www.unaids.org/en/resources/campaigns/2014/2014gapreport/slides/

[2] European Centre for Disease and Prevention Control (ECDC) and WHO (2014) Europe's HIV Response Falls Short in Curbing Epidemic: 80\% More New HIV Cases Compared to 2004. Stockholm/Copenhagen 27/11/2014. Available Online: Press-Release-Hiv-Aids-Europe-Response-Falls-Short-Curbing-Epidemic-27-November-2014.pdf. Additional information:

European Centre for Disease Prevention and Control/WHO Regional Office for Europe. HIV/AIDS Surveillancein Europe 2013. Stockholm: European Centre for Disease Prevention and Control.

http://ecdc.europa.eu/en/publications/_layouts/forms/Publication_DispForm.aspx?List=4f55ad51-4aed-4d32-b960-af70 $113 d b b 90 \& I D=1217$

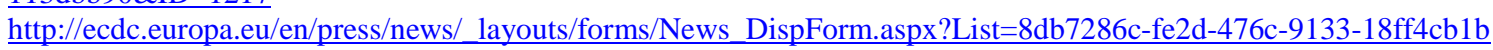
568\&ID=1121

WHO warns on HIV Spread in Europe and Central Asia.

http://www.dw.de/who-warns-on-hiv-spread-in-europe-and-central-asia/a-18092213

[3] European Centre for Disease and Prevention Control (ECDC).

http://ecdc.europa.eu/en/press/news/_layouts/forms/News_DispForm.aspx?List=8db7286c-fe2d-476c-9133-18ff4cb1b 568\&ID=911

Haar, K. and Amato-Gauci, A.J. (2015) European Men Who Have Sex with Men Still at Risk of HIV Infection Despite Three Decades of Prevention Efforts. Eurosurveillance, 20, pii=21087.

http://www.eurosurveillance.org/ViewArticle.aspx?ArticleId=21087

[4] ECDC (2014) Annual Epidemiological Report 2014—STIs including HIV and Blood-Borne Viruses Surveillance Report.

http://ecdc.europa.eu/en/publications/Publications/sexually-transmited-infections-HIV-AIDS-blood-borne-annual-epi-r eport-2014.pdf

[5] Hall, H.I., An, Q., Tang, T., Song, R., Chen, M., Green, T. and Kang, J. (2015) Prevalence of Diagnosed and Undiagnosed HIV Infection-United States, 2008-2012. Morbidity and Mortality Weekly Report, 64, 657-662.

Division of HIV/AIDS Prevention, National Center for HIV/AIDS, Viral Hepatitis, Sexual Transmitted Diseases and Tuberculosis Prevention, Centers for Disease Control and Prevention.

http://www.cdc.gov/hiv/statistics/basics/ataglance.html

[6] Booth, R., Davis, J., Dvoryak, S., Brewster, J., Strathdee, S. and Latkin, C. (2015) Efficacy of a Network Intervention in Reducing HIV Incidence among people Who Inject Drugs in Ukraine: Preliminary Results from a Clustered Randomized Trial. 8th International AIDS Society Conference on HIV Pathogenesis, Treatment, and Prevention (IAS 2015), Vancouver, Abstract TUAC0402.

[7] Pria, A., Springer, S.A., Copenhaver, M.M. and Altice, F.L. (2010) Neurocognitive Impairment and HIV Risk Factors: A Reciprocal Relationship. AIDS and Behavior, 14, 1213-1226.

[8] Singh, R., Manjot, K. and Deepak, A. (2011) Neurological Complications in Late-Stage Hospitalized Patients with HIV Disease. Annals of Indian Academy of Neurology, 14, 172-177. http://dx.doi.org/10.4103/0972-2327.85878

[9] McArthur, J.C, Brew, B.J. and Nath, A. (2005) Neurological Complications of HIV Infection. The Lancet Neurology, 4, 543-555. http://dx.doi.org/10.1016/S1474-4422(05)70165-4

[10] Bracchi, M., Stuart, D., Castles, R., Khoo, S., Back, D. and Boffito, M. (2015) Increasing Use of "Party Drugs” in People Living with HIV on Antiretrovirals: A Concern for Patient Safety. AIDS, S29, 1585-1592. http://dx.doi.org/10.1097/QAD.0000000000000786

[11] Frieden, R.T., Das-Douglas, M., Kellerman, S.E. and Henning, K.J. (2005) Applying Public Health Principles to the HIV Epidemic. New England Journal of Medicine, 353, 2397-2402. http://dx.doi.org/10.1056/NEJMsb053133

[12] Bayer, R. and Fairchild, A.L. (2006) Changing the Paradigm for HIV Testing-The End of Exceptionalism. New England Journal of Medicine, 355, 647-649. http://dx.doi.org/10.1056/NEJMp068153

[13] US Preventive Services Task Force (USPSTF) (2013) Human Immunodeficiency Virus (HIV) Infection: Screening. http://www.uspreventiveservicestaskforce.org/uspstf13/hiv/hivfinalrs.htm

[14] Bayer, R. and Oppenheimer, G.M. (2013) Routine HIV Testing. Public Health, and the USPSTF-An End to the Debate. New England Journal of Medicine, 368, 881-884. http://dx.doi.org/10.1056/NEJMp1214535

[15] Ransomea, Y., Terzianb, A., Addisonc, D., Braunsteinb, S, Myersb, J., Abrahame, B. and Nashc, D. (2015) Expanded HIV Testing Coverage Is Associated with Decreases in Late HIV Diagnoses. AIDS, 29, 1369-1378.

http://dx.doi.org/10.1097/QAD.0000000000000684 
[16] Seth, P., Wang, G., Collins, N.T. and Belcher, L. (2015) Identifying New Positives and Linkage to HIV Medical Care-23 Testing Site Types, United States, 2013. Morbidity and Mortality Weekly Report, 64, 663-667.

[17] Abdool Karim, S.S. (2015) Overcoming Impediments to Global Implementation of Early Antiretroviral Therapy. New England Journal of Medicine, 373, 875-876. http://dx.doi.org/10.1056/NEJMe1508527

[18] Velter, A., Saboni, L., Le Vu, S. and Lot, F. (2014) Pratiques de dépistage VIH des hommes ayant des rapports sexuels avec des hommes. Apports de l’Enquête presse gays et lesbiennes 2011 [HIV Testing Practices among Men Who Have Sex with Men. Results of the Gay and Lesbian Survey 2011 France]. Bulletin Epidemiologique Hebdomaire, 32-33, 541-547. (Article in French, Abstract in English)

[19] Ferrer, L., Furegato, M., Foschia, J.-P., Folch, C., González, V., Ramarli, D., Casabona, J. and Mirandola, M. (2015) Undiagnosed HIV Infection in a Population of MSM from Six European Cities: Results from the SIALON Project. European Journal of Public Health, 25, 494-500. http://dx.doi.org/10.1093/eurpub/cku139

[20] Hernando, V., Alvárez-Del Arco, D., Alejos, B., Monge, S., Amato-Gauci, A.J., Noori, T, Pharris, A. and del Amo, J. (2015) HIV Infection in Migrant Populations in the European Union and European Economic Area in 2007-2012: An Epidemic on the Move. Journal of Acquired Immune Deficiency Syndromes, 70, 204-211. http://www.ncbi.nlm.nih.gov/pubmed/26068723

[21] Desgrees du Lou, A., Pannetier, J.A., Ravalihasy, A., Gosselin, A., Supervie, V., Bajos, N., Lert, F., Lydie, N. and Dray-Spira, R. (2015) HIV Acquisition after Arrival in France among Sub-Saharan African Migrants Living with HIV in Paris Area. Estimations from the ANRS PARCOURS Study. 8th International AIDS Society Conference on HIV Pathogenesis, Treatment, and Prevention, Vancouver, 19-22 July 2015, Abstract WEPDC0103.

[22] Fakoya, I., Álvarez-Del Arco, D., Woode-Owusu, M., Monge, S., Rivero-Montesdeoca, Y., Delpech, V., Rice, B., Noori, T., Pharris, A., Amato-Gauci, A.J., Del Amo, J. and Burns, F.M. (2015) A Systematic Review of Post-Migration Acquisition of HIV among Migrants from Countries with Generalised HIV Epidemics Living in Europe: Mplications for Effectively Managing HIV Prevention Programmes and Policy. BMC Public Health, 15, 561. http://dx.doi.org/10.1186/s12889-015-1852-9

[23] Schultz, A., Phillips, A.N., Paredes, R., Battegay, M., Rockstroh, J.K., Machala, L., Tomazic, J., Girard, P.M., Januskevica, I., Gronborg-Lauti, K., Lundgreni, J.D. and Alessandro Cozzi-Lepria, A., on Behalf of EuroSIDA in EuroCOORD (2015) HIV Resistance Testing and Detected Drug Resistance in Europe. AIDS, 29, 1379-1389. http://dx.doi.org/10.1097/QAD.0000000000000708

[24] Cartwright, C.P. (2006) The Changing Epidemiology of HIV/AIDS at a Minnesota Hospital: Impact of Demographic Change and Viral Diversity. Journal of Medical Virology, 78, S19-S21. http://dx.doi.org/10.1002/jmv.20601

[25] Cooke, G.S. (2015) Hepatitis C Seroprevalence and HIV Co-Infection in Sub-Saharan Africa: A Systematic Review and Meta-Analysis. The Lancet Infectious Diseases, 15, 818-824.

[26] Johnson, W.D., Diaz, R.M., Flanders, W.D., Goodman, M., Hill, A.N., Holtgrave, D., Malow, R. and McClellan, W.M. (2008) Behavioral Interventions to Reduce Risk for Sexual Transmission of HIV among Men Who Have Sex with Men. Cochrane Database of Systematic Reviews, No. 3. Article No.: CD001230. http://dx.doi.org/10.1002/14651858.cd001230.pub2

[27] Crepaz, N., Tungol-Ashmon, M.V., Higa, D.H., Vosburgh, W., Mullins, M.M., Barham, T., Adegbite, A., DeLuca, J.B., Sipe, T.A., White, C.M., Baack, B.N. and Lyles, C.M. (2014) A Systematic Review of Interventions for Reducing HIV Risk Behaviors among People Living with HIV in the United States 1988-2012. AIDS, 28, 633-656. http://dx.doi.org/10.1097/QAD.0000000000000108

[28] Paltiel, A.D., Walensky, R.P, Schackman, B.R, Seage III, G.R, Mercincavage, L.M, Weinstein, M.C. and Freedberg, K.A. (2006) Expanded HIV Screening in the United States: Effect on Clinical Outcomes, HIV Transmission, and Costs. Annals of Internal Medicine, 145, 797-806. http://dx.doi.org/10.7326/0003-4819-145-11-200612050-00004

[29] WHO (2011) Global Health Sector Strategy on HIV/AIDS 2011-2015. http://whqlibdoc.who.int/publications/2011/9789241501651_eng.pdf

[30] Crepaz, N. and Marks, G. (2002) Towards an Understanding of Sexual Risk Behavior in People Living with HIV: A Review of Social, Psychological, and Medical Findings. AIDS, 16, 135-149. http://dx.doi.org/10.1097/00002030-200201250-00002

[31] Malek, R., Mitchell, H., Furegato, M., Simms, I., Mohammed, H., Nardone, A. and Hughes, G. (2015) Contribution of Transmission in HIV-Positive Men Who Have Sex with Men to Evolving Epidemics of Sexually Transmitted Infections in England: An Analysis Using Multiple Data Sources, 2009-2013. Eurosurveillance, 20, pii=21093. http://www.eurosurveillance.org/ViewArticle.aspx?ArticleId=21093 http://dx.doi.org/10.2807/1560-7917.es2015.20.15.21093

[32] ECDC (2013) Technical Report, STI and HIV Prevention in Men Who Have Sex with Men in Europe. http://ecdc.europa.eu/en/publications/publications/sti-hiv-prevention-msm-in-europe-21-feb-2013.pdf

[33] Kouyos, R.D., Hasse, B., Calmy, A., Cavassini, M., Furrer, H., Stöckle, M., Vernazza, P.L., Bernasconi, E., Weber, R., 
Günthard, H.F. and the Swiss HIV Cohort Study (2015) Increases in Condomless Sex in the Swiss HIV Cohort Study. Open Forum Infectious Diseases, 2, ofv077. http://dx.doi.org/10.1093/ofid/ofv077

[34] Fenton, K. (2013) The Resurgent Global HIV Epidemic in Men Who Have Sex with Men (MSM). Plenary Lecture, BHIVA Autumn Conference, London, UK, 2013. Comment by G. Cairns.

http://www.aidsmap.com/page/2805378/?utm_source=NAM-Email-Promotion\&utm_medium=aidsmap-news\&utm_ca mpaign=aidsmap-news

[35] Executive Summary (2012) Special Issue on HIV in Men who have Sex with Men (MSM). Lancet, 380, No. 9893. Jamaica Coalition for a Healthy Society on Sodomy Laws.

http://ionsg.blogspot.de/2013/08/speaking-truth-is-not-homophobia.html

[36] WHO (2011) Global Health Sector Strategy on HIV/AIDS 2011-2015.

http://www.who.int/hiv/pub/hiv strategy/en/

[37] Marcellin, F., Lorente, N., Demoulin, B., Carrieri, M.P., Suzan-Monti, M., Roux, P., Lert, F., Sagaon-Teyssier, L., Dray-Spira, R. and Spire, B. (2015) Comparison of Risk Factors in HIV-Infected Men Who Have Sex with Men, Coinfected or Not with Hepatitis C Virus. Sexually Transmitted Infections, 91, 21-23. http://dx.doi.org/10.1136/sextrans-2014-051542

[38] Midgard, H., Bjøro, B. and Dalgard, O. (2015) Incidence of Hepatitis C Reinfection Following Sustained Virologic Response-A Seven Year Follow-Up of Scandinavian Patients Infected through Injecting Drug Use. 50th Annual Meeting of the European Association for the Study of the Liver, Vienna, 22-26 April 2015, Abstract O061. http://ilc-congress.eu/abstract_25_04/ILC2015-abstract-book-25-04-Saturday.pdf

[39] Halkitis, P., Kapadia, F. and Ompad, D. (2015) Incidence of HIV Infection in Young Gay, Bisexual, and Other YMSM: The P18 Cohort Study. JAIDS Journal of Acquired Immune Deficiency Syndromes, 69, 466-473. http://dx.doi.org/10.1097/qai.0000000000000616

[40] Ostrow, D.E., Fox, K.J., Chmiel, J.S., Silvestre, A., Visscher, B.R., Vanable, P.A., Jacobson, L.P. and Strathdee, S.A. (2002) Attitudes towards Highly Active Antiretroviral Therapy Are Associated with Sexual Risk Taking among HIVInfected and Uninfected Homosexual Men. AIDS, 16, 775-780. http://dx.doi.org/10.1097/00002030-200203290-00013

[41] Stolte, I.G., Dukers, N.H., Geskus, R.B., Coutinho, R.A. and de Wit, J.B. (2004) Homosexual Men Change to Risky Sex When Perceiving Less Threat of HIV/AIDS since Availability of Highly Active Antiretroviral Therapy: A Longitudinal Study. AIDS, 18, 303-309. http://dx.doi.org/10.1097/00002030-200401230-00021

[42] Bezemer, D., de Wolf, F., Boerlijst, M.C., van Sighem, A., Hollingsworth, T.D., Prinsd, M., Geskus, R.B., Gras, L., Coutinho, R.A. and Fraser, C. (2008) A Resurgent HIV-1 Epidemic among Men Who Have Sex with Men in the Era of Potent Antiretroviral Therapy. AIDS, 22, 1071-1077. http://dx.doi.org/10.1097/QAD.0b013e3282fd167c

[43] European Centre for Disease and Prevention Control, WHO Europe (2013) HIV/AIDS Surveillance in Europe 2013. http://ecdc.europa.eu/en/publications/Publications/hiv-aids-surveillance-report-Europe-2013.pdf

[44] Baggaley, R.F., White, R.G. and Boily, M.-C. (2010) HIV Transmission Risk through Anal Intercourse: Systematic Review, Meta-Analysis and Implications for HIV Prevention. International Journal of Epidemiology, 39, 1048-1063. http://dx.doi.org/10.1093/ije/dyq057

[45] UK HIV Drug Resistance Collaboration (2009) Molecular Phylodynamics of the Heterosexual HIV Epidemic in the United Kingdom. PLoS Pathogens, 5, e1000590. http://dx.doi.org/10.1371/journal.ppat.1000590

[46] Van de Laar, T., Pybus, O., Bruisten, S., Brown, D., Nelson, M., Bhagani, S., Vogel, M., Baumgarten, A., Chaix, M.L., Fisher, M., Gőtz, H., Matthews, G., Neifer, S., White, P., Rawlinson, W., Pol, S., Rockstroh, J., Coutinho, R., Dore, G., Dusheiko, G. and Danta, M. (2009) Evidence of a Large, International Network of HCV Transmission in HIV-Positive Men Who Have Sex with Men. Gastroenterology, 136, 1609-1617. http://dx.doi.org/10.1053/j.gastro.2009.02.006

[47] Sanchez, T.H., Kelley, C.F., Rosenberg, E., Luisi, N., O’Hara, B., Lambert, R., Coleman, R., Frew, P., Salazar, L.F., Tao, S., Clarke, W., Del Rio, C. and Sullivan, P.S. (2014) Lack of Awareness of Human Immunodeficiency Virus (HIV) Infection: Problems and Solutions with Self-Reported HIV Serostatus of Men Who Have Sex with Men. Open Forum Infectious Diseases, 1, ofu084. http://dx.doi.org/10.1093/ofid/ofu084

[48] Zimbardo, P. (2007) The Lucifer Effect-Understanding How People Turn Evil. Rider, London.

[49] Beck, U. (1992) Risk Society: Towards a New Modernity. Sage, London.

Beck, U. (1986) Risikogesellschaft, Auf dem Weg in eine andere Moderne Taschenbuch. Edition Suhrkamp, Frankfurt. (in German)

[50] Sharp, P.M. and Hahn, B.H. (2011) Origins of HIV and the AIDS Pandemic. Cold Spring Harbor Perspectives in Medicine, 1, a006841. http://dx.doi.org/10.1101/cshperspect.a006841

[51] Heeney, J.L., Dalgleish, A.G. and Weiss, R.A. (2006) Origins of HIV and the Evolution of Resistance to AIDS. Science, 313, 462-466. http://dx.doi.org/10.1126/science.1123016 
[52] Faria, N.R., Rambaut, A., Suchard, M.A., Baele, G., Bedford, T., Ward, M.J., Tatem, A.J., Sousa, J.D., Arinaminpathy, N., Pépin, J., Posada, D., Peeters, M., Pybus, O.G. and Lemey, P. (2014) HIV Epidemiology. The Early Spread and Epidemic Ignition of HIV-1 in Human Populations. Science, 346, 56-61. http://dx.doi.org/10.1126/science.1256739

[53] Bayer, R. and Fairchild, A.L. (2004) The Genesis of Public Health Ethics. Bioethics, 18, 473-492. http://dx.doi.org/10.1111/j.1467-8519.2004.00412.x

[54] UNAIDS (2006) International Guidelines on HIV/AIDS and Human Rights. 2006 Consolidated Version, Geneva.

[55] WHO Europe. "HIV/AIDS, Data and Statistics". http://www.euro.who.int/en/health-topics/communicable-diseases/hivaids/data-and-statistics

[56] Committee on Economic, Social and Cultural Rights (CESCR) (1976) International Covenant on Economic, Social and Cultural Rights. http://www.ohchr.org/Documents/ProfessionalInterest/cescr.pdf

[57] Gostin, L.O. and Lazzarini, Z. (1997) International Human Rights Law in the AIDS Pandemic. Human Rights and Public Health in the AIDS Pandemic. Oxford University Press, New York, Oxford, 1-42.

[58] Gregson, S., Hallett, T.B., Stover, J. and Ghys, P.D. (2013) Putting the Burden of HIV in Context. AIDS, 27, 21612162. http://dx.doi.org/10.1097/QAD.0b013e3283638641

[59] Ortblad, K.F., Lozano, R. and Murray, C.J. (2013) The Burden of HIV: Insights from the Global Burden of Disease Study 2010. AIDS, 27, 2003-2017. http://dx.doi.org/10.1097/QAD.0b013e328362ba67

[60] Glass, R.I. (2014) HIV/AIDS and Noncommunicable Disease Comorbidities: Emerging Research Priorities. Journal of Acquired Immune Deficiency Syndromes, 67, S1. http://dx.doi.org/10.1097/qai.0000000000000266

[61] Rueda, S., Law, S. and Rourke, S.B. (2014) Psychological, Mental Health, and Behavioral Issues of Aging with HIV. Current Opinion in HIV and AIDS, 9, 325-331. http://dx.doi.org/10.1097/COH.0000000000000071

[62] Shrestha, R.K., Gardner, L., Marks, G., Craw, J., Malitz, F., Giordano, T.P., Sullivan, M., Keruly, J., Rodriguez, A., Wilson, T.E. and Mugavero, M. (2015) Estimating the Cost of Increasing Retention in Care for HIV-Infected Patients. Journal of Acquired Immune Deficiency Syndromes, 68, 345-350. http://dx.doi.org/10.1097/QAI.0000000000000462

[63] Underhill, K. (2012) Paying for Prevention: Challenges to Health Insurance Coverage for Biomedical HIV Prevention in the United States. American Journal of Law \& Medicine, 38, 607-666.

[64] Finance and Economics (2004) The Cost of AIDS: An Imprecise Catastrophe. The Economist (US), 22 May 2004, 82-83. http://www.economist.com/node/2693350

[65] Nakagawa, F., Miners, A., Smith, C.J., Simmons, R., Lodwick, R.K., Cambiano, V., Lundgren, J.D., Delpech, V. and Phillips, A.N. (2015) Projected Lifetime Healthcare Costs Associated with HIV Infection. PLoS ONE, 10, e01205018. http://dx.doi.org/10.1371/journal.pone.0125018

[66] Stoll, M., Kuhlmann, A., Treskova, M., Bogner, J., Hower, M., Stellbrink, H.J., Heiken, H., Gerschmann, S., Klauke, S., Lutz, T., Degen, O., van Lunzen, J., Bachmann, C., Schmidt, W., Leistner, I., Holm, S., Mahlich, J. and CORSAR-Studiengruppe (2015) Identifikation von Prädiktoren der Krankheitskosten von HIV/AIDS in Deutschland in einem multiplen Regressionsmodell. Deutsch Österreichischer AIDS Kongress, Düsseldorf, 24-27 June 2015, Abstract V7.

[67] Schackman, B.R., Gebo, K.A., Walensky, R.P., Losina, E., Muccio, T., Sax, P.E., Weinstein, M.C., Seage III, G.R., Moore, R.D. and Freedberg, K.A. (2006) The Lifetime Cost of Current Human Immunodeficiency Virus Care in the United States. Medical Care, 44, 990-997. http://dx.doi.org/10.1097/01.mlr.0000228021.89490.2a

[68] Sloan, C.E., Champenois, K., Choisy, P., Losina, E., Walensky, R.P., Schackman, B.R., Ajana, F., Melliez, H., Paltiel, A.D., Freedberg, K.A. and Yazdanpanah, Y., Cost-Effectiveness of Preventing AIDS Complications (CEPAC) Investigators (2012) Newer Drugs and Earlier Treatment: Impact on Lifetime Cost of Care for HIV-Infected Adults. AIDS, 26, 45-56. http://dx.doi.org/10.1097/QAD.0b013e32834dce6e

[69] Lau, K.A. and Wong, J.J.L. (2013) Current Trends of HIV Recombination Worldwide. Infectious Disease Reports, 5, 15-20. http://dx.doi.org/10.4081/idr.2013.s1.e4

[70] UNAIDS. Criminalization of HIV Transmission-Policy Brief. http://www.unaids.org/sites/default/files/en/media/unaids/contentassets/dataimport/pub/basedocument/200 8/20080731_jc1513_policy_criminalization_en.pdf

[71] NAM Aidsmap (2015) Challenges Associated with Disclosing One’s HIV-Positive Status. http://www.aidsmap.com/Challenges-associated-with-disclosing-ones-HIV-positive-status/page/1442642/

[72] Upton, C.T., Taiwo, B. and Robertson, K.R. (2013) HIV-Associated Neurocognitive Disorders. Future Virology, 8, 469-475. http://dx.doi.org/10.2217/fvl.13.30

[73] Open Society Foundations (2008) Ten Reasons to Oppose the Criminalization of HIV Exposure or Transmission. http://www.opensocietyfoundations.org/publications/ten-reasons-oppose-criminalization-hiv-exposure-or-transmission 
[74] Rayment, M., on Behalf of the BASHH and BHIVA Audit Committees (2013) HIV Partner Notification: Findings of the Joint BHIVA/BASHH Audit. For the 2013 BHIVA Autumn Conference Presentations. London 14-15 November 2013. Comment by G. Cairns "Partner Notification Highly Effective at Finding New HIV Cases, but a Third Who Could Be Tested Are Missed.”

http://www.aidsmap.com/page/2804912/?utm_source=NAM-Email-Promotion\&utm_medium=aidsmap-news\&utm_ca mpaign=aidsmap-news

[75] Zhu, T., Korber, B.T., Nahmias, A.J., Hooper, E., Sharp, P.M. and Ho, D.D. (1998) An African HIV-1 Sequence from 1959 and Implications for the Origin of the Epidemic. Nature, 391, 594-597. http://dx.doi.org/10.1038/35400

[76] McCarthy, K.R., Kirmaier, A., Autissier, P. and Johnson, W.E. (2015) Evolutionary and Functional Analysis of Old World Primate TRIM5 Reveals the Ancient Emergence of Primate Lentiviruses and Convergent Evolution Targeting a Conserved Capsid Interface. PLoS Pathogens, 11, e1005085. http://dx.doi.org/10.1371/journal.ppat.1005085

[77] Mousseau, G., Kessing, C.F., Fromentin, R., Trautmann, L., Chomont, N. and Valente, S.T. (2015) The Tat Inhibitor Didehydro-Cortistatin A Prevents HIV-1 Reactivation from Latency. mBio, 6, e00465-15. http://dx.doi.org/10.1128/mbio.00465-15

[78] Sturdevant, C.B., Joseph, S.B., Schnell, G., Price, R.W., Swanstrom, R. and Spudich, S. (2015) Compartmentalized Replication of R5 T Cell-Tropic HIV-1 in the Central Nervous System Early in the Course of Infection. PLoS Pathogens, 11, e1004720. http://dx.doi.org/10.1371/journal.ppat.1004720

Affiliation: Lineberger Comprehensive Cancer Center, University of North Carolina at Chapel Hill, Chapel Hill.

[79] Agosto, L.M., Uchil, P.D. and Mothes, W. (2015) HIV Cell-to-Cell Transmission: Effects on Pathogenesis and Antiretroviral Therapy. Trends in Microbiology, 23, 289-295. http://dx.doi.org/10.1016/j.tim.2015.02.003

[80] Gaardbo, J.C., Hartling, H.J., Gerstoft, J. and Nielsen, S.D. (2012) Thirty Years with HIV Infection—Nonprogression Is Still Puzzling: Lessons to Be Learned from Controllers and Long-Term Nonprogressors. AIDS Research and Treatment, 2012, Article ID: 161584. http://dx.doi.org/10.1155/2012/161584

[81] Maldarelli, F., Kearney, M., Palmer, S., Stephens, R., Mican, J.A., Polis, M.A., Davey, R.T., Kovacs, J., Shao, W., Rock-Kress, D., Metcalf, J.A., Rehm, C., Greer, S.E., Lucey, D.L., Danley, K., Alter, H., Mellors, J.W. and Coffin, J.M. (2013) HIV Populations Are Large and Accumulate High Genetic Diversity in a Nonlinear Fashion. Journal of Virology, 87, 10313-10323. http://dx.doi.org/10.1128/JVI.01225-12

[82] Mbisa, J.L., Fearnhill, E., Dunn, D.T., Pillay, D., Asboe, D. and Cane, P.A., on Behalf of the UK HIV Drug Resistance Database (2015) Evidence of Self-Sustaining Drug Resistant HIV-1 Lineages among Untreated Patients in the UK. Clinical Infectious Diseases, 61, 829-836. http://dx.doi.org/10.1093/cid/civ393

[83] Kouyos, R.D., Huldrych, F. and Günthard, H.F. (2015) Editorial Commentary: The Irreversibility of HIV Drug Resistance. Clinical Infectious Diseases, 61, 837-839. http://dx.doi.org/10.1093/cid/civ400

[84] Turk, G. and Carobene, M.G. (2015) Deciphering How HIV-1 Intersubtype Recombination Shapes Viral Fitness and Disease Progression. EBioMedicine, 2, 188-189. http://dx.doi.org/10.1016/j.ebiom.2015.02.011

[85] Peeters, M. (2015) Recombinant HIV Sequences: Their Role in the Global Epidemic. http://www.hiv.lanl.gov/content/immunology/pdf/2000/1/Peeters.pdf

[86] Perrin, L., Kaiser, L. and Yerly, S. (2003) Travel and the Spread of HIV-1 Genetic Variants. Lancet Infectious Diseases, 3, 22-27. http://dx.doi.org/10.1016/S1473-3099(03)00484-5

[87] Angelis, K., Albert, J., Mamais, I., Magiorkinis, G., Hatzakis, A., Hamouda, O., Struck, D., Vercauteren, J., Wensing, A.M.J., Alexiev, I., Åsjö, B., Balotta, C., Camacho, R.J., Coughlan, S., Griskevicius, A., Grossman, Z., Horban, A., Kostrikis, L.G., Lepej, S., Liitsola, K., Linka, M., Nielsen, C., Otelea, D., Paredes, R., Poljak, M., Puchhammer-Stöckl, E., Schmit, J.-C., Sönnerborg, A., Staneková, D., Stanojevic, M., Boucher, C.A.B., Kaplan, L., Vandamme, A.-M. and Paraskevis, D. (2014) Global Dispersal Pattern of HIV Type 1 Subtype CRF01_AE: A Genetic Trace of Human Mobility Related to Heterosexual Sexual Activities Centralized in Southeast Asia. The Journal of Infectious Diseases, 211, 1735-1744. http://dx.doi.org/10.1093/infdis/jiu666

[88] Kouri, V., Khouri, R., Alemán,YY., Abrahantes, Y., Vercauteren, J., Pineda-Peña, A.-C., Theys, K., Megens, S., Moutschen, M., Pfeifer, N., Van Weyenbergh, J., Pérez, A.B., Pérez, J., Pérez, L., Van Laethem, K. and Vandamme, A.-M. (2015) CRF19_cpx Is an Evolutionary Fit HIV-1 Variant Strongly Associated with Rapid Progression to AIDS in Cuba. EBioMedicine, 2, 244-254. http://dx.doi.org/10.1016/j.ebiom.2015.01.015

[89] Luft, L.A.M., Gill, M.J. and Church, D.L. (2011) HIV-1 Viral Diversity and Its Implications for Viral Load Testing: Review of Current Platforms. International Journal of Infectious Diseases, 15, e661-e670. http://dx.doi.org/10.1016/j.ijid.2011.05.013

[90] Fox, J., Castro, H., Kaye, S., McClure, M., Weber, J.N. and Fidler, S., UK Collaborative Group on HIV Drug Resistance (2010) Epidemiology of Non-B Clade Forms of HIV-1 in Men Who Have Sex with Men in the UK. AIDS, 24, 2397-2401. http://dx.doi.org/10.1097/qad.0b013e32833cbb5b 
[91] The UK Collaborative Group on HIV Drug Resistance (2014) The Increasing Genetic Diversity of HIV-1 in the UK, 2002-2010. AIDS, 28, 773-780.

[92] Cohen, J. (2010) Tracing the Regional Rise of HIV. Science, 329, 161. http://dx.doi.org/10.1126/science.329.5988.161

[93] Lihana, R.W., Ssemwanga, D., Abimiku, A. and Ndembi, N. (2012) Update on HIV-1 Diversity in Africa: A Decade in Review. AIDS Reviews, 14, 83-100.

[94] Lau, K.A., Wang, B. and Saksena, N.K. (2007) Emerging Trends of HIV Epidemiology in Asia. AIDS Reviews, 9, 218-229.

[95] Abrahams, M.-R., Treurnicht, F.K., Ngandu, N.K., Goodier, S.A., Marais, J.C., Bredell, H., Thebus, R., de Assis Rosa, D., Mlisana, K., Seoighe, C., Karim, S.A., Gray, C.M. and Williamson, C., the Centre for the AIDS Program of Research in South Africa Acute Infection Study Team and the Center for HIV-AIDS Vaccine Immunology Consortium (2013) Rapid, Complex Adaptation of Transmitted HIV-1 Full-Length Genomes in Subtype C-Infected Individuals with Differing Disease Progression. AIDS, 27, 507-518. http://dx.doi.org/10.1097/QAD.0b013e32835cab64

[96] Deogratiusa, S., Lyagoba, F., Ndembi, N., Mayanja, B.N., Larke, N., Wang, S., Baalwa, J., Williamson, C., Grosskurth, H. and Kaleebua, P. (2011) Multiple HIV-1 Infections with Evidence of Recombination in Heterosexual Partnerships in a Low Risk Rural Clinical Cohort in Uganda. Virology, 411, 113-131. http://dx.doi.org/10.1016/j.virol.2010.12.025

[97] Fauci, A.S. and Marston, H.D. (2015) Focusing to Achieve a World without AIDS. JAMA, 313, 357-358. http://dx.doi.org/10.1001/jama.2014.17454

[98] UNAIDS (2014) Fast-Track: Ending the AIDS Epidemic by 2030. http://www.unaids.org/sites/default/files/media_asset/JC2686_WAD2014report_en.pdf

[99] Lima, V.D., Bangsberg, D.R., Harrigan, P.R., Deeks, S.G., Yip, B., Hogg, R.S. and Montaner, J.S. (2010) Risk of Viral Failure Decline with Duration of Suppression on Highly Antiretroviral Therapy Irrespective of Adherence Level. Journal of Acquired Immune Deficiency Syndromes, 55, 460-465. http://dx.doi.org/10.1097/QAI.0b013e3181f2ac87

[100] McCormack, S. and Dunn, D., PROUD Study Group (2015) Pragmatic Open-Label Randomised Trial of Preexposure Prophylaxis: The PROUD Study. Abstract 22LB.

Molina, J.M., Capitant, C., Spire, B., Pialoux, G., Chidiac, C., Charreau, I., et al., ANRS Ipergay Study Group (2015) On Demand PrEP with Oral TDF-FTC in MSM: Results of the ANRS Ipergay Trial, Abstract 23LB. Conference on Retroviruses and Opportunistic Infections (CROI), Seattle, 23-24 February 2015. Comment by Jim Kling. http://www.medscape.com/viewarticle/840402\#vp_2

[101] Keith, A. (2011) Is HIV Drug Resistance Spreading? Early Warning Signals Say “Yes”. Comments from the Eighteenth Conference on Retroviruses and Opportunistic Infections, Boston, 2011. http://www.aidsmap.com/print/Is-HIV-drug-resistance-spreading-Early-warning-signals-say-yes/page/1684209/\#

[102] World Health Organization (2012) WHO HIV Drug Resistance Report 2012. http://apps.who.int/iris/bitstream/10665/75183/1/9789241503938_eng.pdf

[103] Haberer, J.E., Bangsberg, D.R., Baeten, J.M., Curran, K., Koechlin, F., Amico, K.R., Anderson, P., Mugo, N., Venter, F., Goicochea, P., Caceres, C. and O’Reilly, K. (2015) Defining Success with HIV Pre-Exposure Prophylaxis: A Prevention-Effective Adherence Paradigm. AIDS, 29, 1277-1285. http://dx.doi.org/10.1097/QAD.0000000000000647

[104] McNairy, M.L. and El-Sadr, W.M. (2014) Antiretroviral Therapy for the Prevention of HIV Transmission: What Will It Take? Clinical Infectious Diseases, 58, 1003-1011. http://dx.doi.org/10.1093/cid/ciu018

[105] Beyrer, Ch., et al. (2015) The Vancouver Consensus. The 8th International AIDS Society Conference on HIV Pathogenesis, Treatment and Prevention, Vancouver, 19-22 July 2015. http://vancouverconsensus.org/

[106] Martin, M., Vanichseni, S., Suntharasamai, P., Sangkum, U., Mock, P.A., Leethochawalit, M., Chiamwongpaet, S., Curlin, M.E., Na-Pompet, S., Warapronmongkholkul, A., Kittimunkong, S., Gvetadze, R.J., McNicholl, J.M., Paxton, L.A. and Choopanya, K., the Bangkok Tenofovir Study Group (2015) The Impact of Adherence to Preexposure Prophylaxis on the Risk of HIV Infection among People Who Inject Drugs. AIDS, 29, 819-824. http://dx.doi.org/10.1097/QAD.0000000000000613

[107] Winand, R., Theys, K., Eusébio, M., Aerts, J., Camacho, R.J., Gomes, P., Suchard, M.A., Vandamme, A.-M., Abecasis, A.B. and Portuguese HIV-1 Resistance Study Group (2015) Assessing Transmissibility of HIV-1 Drug Resistance Mutations from Treated and from Drug-Naive Individuals. AIDS, S29, 2045-2052. http://dx.doi.org/10.1097/QAD.0000000000000811

[108] Gupta, R.K., Jordan, M.R, Sultan, B.J., Hill, A., Davis, D.H.J., Gregson, J., Sawyer, A.W., Hamers, R.L., Ndembi, N., Pillay, D. and Bertagnolio, S. (2012) Global Trends in Antiretroviral Resistance in Treatment-Naïve Individuals with HIV after Rollout of Antiretroviral Treatment in Resource-Limited Settings: A Global Collaborative Study and Meta-Regression Analysis. Lancet, 380, 1250-1258. http://dx.doi.org/10.1016/S0140-6736(12)61038-1

[109] McFaul, K.M., Lim, C., Jones, R., Asboe, D., Pozniak, A., Sonecha, S., Boffito, M. and Nwokolo, N. (2014) Transmitted Antiretroviral Drug Resistance in Treatment Naïve HIV-Infected Persons in London in 2011 to 2013. Journal of 
the International AIDS Society, 17, 19747. http://dx.doi.org/10.7448/IAS.17.4.19747

[110] Pillay, D. and Fisher, M. (2007) Primary HIV Infection, Phylogenetics, and Antiretroviral Prevention. The Journal of Infectious Diseases, 195, 924-926. http://dx.doi.org/10.1086/512090

[111] Pilcher, H. (2004) HIV Outpaces Global Response. http://dx.doi.org/10.1038/news040705-5 2004 Report on the Global AIDS Epidemic. Joint United National Programme on HIV/AIDS. http://www.unaids.org/bangkok2004/report/html

[112] El-Sadr, W.M., Harripersaud, K. and Bayer, R. (2014) End of AIDS-Hyper versus Hope. Science, 345, 166. http://dx.doi.org/10.1126/science.1255795

[113] Milstein B. (2006) An Introduction to Syndemics: Implications for Health Promotion. Syndemics Prevention Network, Centers for Disease Control and Prevention. https://www.google.de/?gws_rd=ssl\#q=Milstein+Introduction+to+syndemics

[114] Merson, M.H., O’Malley, J., Serwadda, D. and Apisuk, C. (2008) The History and Challenge of HIV Prevention. Lancet, 372, 475-488. http://dx.doi.org/10.1016/S0140-6736(08)60884-3

[115] Kelly, J.A. (2000) HIV Prevention Interventions with Gay or Bisexual Men and Youth. AIDS, 14, S34-S39.

\section{Abbreviations}

CDC, Center of Disease and Prevention Control/USA; ECDC, European Center of Disease and Prevention Control, Stockholm; HAND, HIV Associated Neurocognitive Disorders; IDU, Injecting Drug User; MSM, Men Sex with Men; NGO, Non-Government Organization; NPH, New Public Health; PLWHA, People Living with HIV/ AIDS; PWID, People Who Inject Drugs (IDU); STI, Sexually Transmitted Infections; TAT, Trans Activator Proteins (Regulatory Proteins of HIVs); TDR, Transmitted Drug Resistance; WHO, World Health Organization; UAI, Unprotected Anal Intercourse. 